\title{
Propolis in Metabolic Syndrome and Its Associated Chronic Diseases: A Narrative Review
}

\author{
Felix Zulhendri ${ }^{1, * \mathbb{D}}$, Munir Ravalia ${ }^{2, *}$, Krishna Kripal ${ }^{3}$, Kavita Chandrasekaran ${ }^{4} \mathbb{D}$, James Fearnley ${ }^{5}$ \\ and Conrad O. Perera $6, *$ (iD)
}

Citation: Zulhendri, F.; Ravalia, M.; Kripal, K.; Chandrasekaran, K.; Fearnley, J.; Perera, C.O. Propolis in Metabolic Syndrome and Its Associated Chronic Diseases: A Narrative Review. Antioxidants 2021, 10, 348. https://doi.org/10.3390/ antiox 10030348

Academic Editor: Claudia Penna

Received: 2 February 2021

Accepted: 23 February 2021

Published: 26 February 2021

Publisher's Note: MDPI stays neutral with regard to jurisdictional claims in published maps and institutional affiliations.

Copyright: (C) 2021 by the authors. Licensee MDPI, Basel, Switzerland. This article is an open access article distributed under the terms and conditions of the Creative Commons Attribution (CC BY) license (https:// creativecommons.org/licenses/by/ $4.0 /)$.
1 Kebun Efi, North Sumatra 2217, Indonesia

2 The Royal London Hospital, Whitechapel Rd, Whitechapel, London E1 1FR, UK

3 Rajarajeswari Dental College \& Hospital, No.14, Ramohalli Cross, Mysore Road, Kumbalgodu, Bengaluru 560074, Karnataka, India; kripalkrishna@yahoo.com

4 Peerzadiguda, Uppal, Hyderabad 500039, Telangana, India; dr.ckavita@gmail.com

5 Apiceutical Research Centre, Unit 3b Enterprise Way, Whitby, North Yorkshire YO18 7NA, UK; james.fearnley@beearc.com

6 Food Science Program, School of Chemical Sciences, University of Auckland, 23 Symonds Street, Auckland CBD, Auckland 1010, New Zealand

* Correspondence: felix.zulhendri@gmail.com (F.Z.); munirrav@yahoo.co.uk (M.R.); conradperera@gmail.com (C.O.P.)

\begin{abstract}
Propolis is a resinous product collected by bees from plants to protect and maintain the homeostasis of their hives. Propolis has been used therapeutically by humans for centuries. This review article attempts to analyze the potential use of propolis in metabolic syndrome (MetS) and its associated chronic diseases. MetS and its chronic diseases were shown to be involved in at least seven out of the top 10 causes of death in 2019. Patients with MetS are also at a heightened risk of severe morbidity and mortality in the present COVID-19 pandemic. Propolis with its antioxidant and anti-inflammatory properties is potentially useful in ameliorating the symptoms of MetS and its associated chronic diseases. The aim of this article is to provide a comprehensive review on propolis and its therapeutic benefit in MetS and its chronic diseases, with an emphasis on in vitro and in vivo studies, as well as human clinical trials. Moreover, the molecular and biochemical mechanisms of action of propolis are also discussed. Propolis inhibits the development and manifestation of MetS and its chronic diseases by inhibiting of the expression and interaction of advanced glycation end products (AGEs) and their receptors (RAGEs), inhibiting pro-inflammatory signaling cascades, and promoting the cellular antioxidant systems.
\end{abstract}

Keywords: propolis; metabolic syndrome; antioxidant; anti-inflammation; chronic diseases; cardiovascular; diabetes mellitus; chronic kidney disease; fatty liver disease; Alzheimer's disease

\section{Introduction}

The top ten causes of death in 2019 listed by the World Health Organization (WHO) showed seven out of 10 leading causes of death were non-communicable diseases, namely, ischemic heart disease, stroke, Alzheimer's disease (and other dementias), cancers, diabetes mellitus, and kidney disease [1]. Metabolic syndrome (MetS) has been shown to significantly increase the risk of these chronic diseases [2-10]. The economic burden to the health service of a patient with MetS is often a few-fold higher compared to a patient without MetS [11]. MetS and its associated chronic diseases also greatly increase morbidity and mortality in viral infections, such as COVID-19 [12-15]. Consequently, MetS has become a major public health challenge all around the world [16-18].

MetS is a cluster of risk factors; abdominal obesity (population specific), increased triglycerides $(\geq 150 \mathrm{mg} / \mathrm{dL}$ or $\geq 1.7 \mathrm{mmol} / \mathrm{L})$, reduced HDL $(<40 \mathrm{mg} / \mathrm{dL}$ for men and $<50 \mathrm{mg} / \mathrm{dL}$ for women), increased blood pressure (systolic $\geq 130 \mathrm{~mm} \mathrm{Hg}$ and/or diastolic $\geq 85 \mathrm{~mm} \mathrm{Hg}$ ), and increased fasting glucose (>100 mg/dL or $5.5 \mathrm{mmol} / \mathrm{L}$ ) [19-21]. 
Lifestyle and dietary factors are considered the main drivers of MetS [22-24]. In addition to lifestyle changes, nutraceutical supplementations such as micronutrients, pro- and prebiotics, polyphenols, plant extracts, and other natural products have been shown to be effective in ameliorating the severity of MetS symptoms [25-32].

The present study attempts to review the potential therapeutic use of propolis in MetS and its associated chronic diseases. Propolis is plant resin collected by bees. The precise composition of propolis varies depending on the source. It comprises wax, resin, balsam, essential oils, pollen, and other bioactive compounds such as amino acids, minerals, vitamins, phenolics, flavonoids, and terpenoids [33-35]. The exact content of propolis is variable depending on the source [36]. Propolis is important in the survival of a bee colony as it serves several crucial functions, namely, maintenance of hive homeostasis, physical protection, antimicrobial action, detoxification processes, immune modulation, and stabilization of the beneficial microbiome [37-42].

The oldest record of the use of bee products by humans dates back to c. 13,000 BCE. Ancient Egyptians, Greeks and Romans used propolis to alleviate many ailments [43]. Recent studies have demonstrated that propolis has a wide range of therapeutic and health benefits for humans, such as antibacterial, antiviral, anti-inflammation, antioxidant, and antiproliferative effects [44-49]. Recently, propolis has also been shown to be a potential therapeutic agent against SARS-CoV-2 and COVID-19 disease [50-52]. The term "propolis" in this review study includes propolis from all propolis-producing bees, namely, European honey bees (Apis mellifera), Asian honey bees (Apis cerana), and stingless bees of the genera Trigona, Melipona, Geniotrigona, Heterotrigona, and Tetragonula.

\section{Cardiovascular Diseases (CVDs)}

\subsection{Atherosclerosis}

Atherosclerosis is the major cause of CVD and has been shown to be strongly associated with oxidation and inflammation. Increased production of reactive oxygen species (ROS) damages the functions of cellular lipids, proteins, and carbohydrates. Increased ROS also induces lipid peroxidation. Oxidation of lipoproteins is the initial stage of atherosclerosis. The development and progression of the pathophysiology of atherosclerosis have been shown to significantly involve the dysregulation of immune-related physiology and inflammatory responses [53-57]. There is an ongoing debate with regard to which lipoprotein is the most important in the formation of atherosclerotic plaque: low-density lipoproteins (LDLs), small dense LDL, VLDL, or remnant cholesterol [58-60].

Oxidized lipoproteins promote endothelial cell damage and endothelial dysfunction. The endothelial dysfunction causes the recruitment of leukocytes in subendothelial space of the tunica intima (the innermost layer of an artery) and induces the secretion of proinflammatory cytokines such as tumor necrosis factor alpha (TNF- $\alpha$ ), interleukin-1 (IL-1), IL-4, IL-6, and interferon gamma (IFN- $\gamma$ ). The cytokines upregulate the expression of various leukocyte adhesion molecules such as vascular cell adhesion molecule-1 (VCAM-1), intercellular adhesion molecule-1 (ICAM-1), and E-selectin [61]. The adhesion molecules further recruit and bind to circulating monocytes and T-lymphocytes. Monocytes, in the subendothelial space, subsequently differentiate into macrophages through monocyte chemotactic protein-1 (MCP-1), macrophage colony-stimulating factor (M-CSF), and IL8. These macrophages recognize and scavenge the oxidized lipids which results in the formation of foam cells. These foam cells then undergo apoptosis and create cellular debris and lipids [53-57]. The resulting inflammatory cascades and lipid-laden foam cells release various cytokines and growth factors that promote the migration of smooth muscle cells (SMCs) from middle layer of the artery walls (tunica media) to the tunica intima. Once in the intima, the SMCs then proliferate and produce an array of extracellular matrix (ECM) in the process of atheroma formation which consequently blocks blood vessels. SMC-derived ECM forms a fibrous cap over the plaque. The collagen degradation of the ECM would consequently rupture the plaque, which triggers the release of pro-coagulation factors that lead to thrombosis and myocardial infarction [53-57]. 
Propolis has been shown to have cardioprotective properties. Claus et al. (2000) showed that the aqueous extract of propolis and its component, propol, reduced $\mathrm{Cu}^{2+}$ induced oxidation of LDL in vitro. They also showed that the extract reduced oxidized LDL-induced macrophage apoptosis [62]. Propolis extract reduced the activity of activated macrophages and the expression of the matrix metalloproteinase-9 (MMP-9) gene in a dose-dependent manner [63]. Matrix metalloproteinases are involved in the degradation of proteins and proteoglycan components of extracellular matrix (ECM) which contributes to the pathogenesis of atherosclerosis [64]. Propolis and its polyphenols were also shown to inhibit platelet aggregation (anticoagulation) in vitro [65].

The cardioprotective property of propolis was demonstrated in various animal studies. Daleprane et al. (2012) found that three types of Brazilian propolis extracts, red, green, and brown, increased the expression of the metalloproteinase inhibitor TIMP-1 while reducing the expression of VCAM, MCP-1, fibroblast growth factor (FGF), platelet-derived growth factor (PDGF), vascular endothelial growth factor (VEGF), platelet endothelial cell adhesion molecule (PECAM), and MMP-9 genes in LDL receptor gene (LDLr-/-) knockout mice [66]. They demonstrated that all three types of propolis significantly inhibited the early development atherosclerotic lesions. However, only red propolis inhibited the advanced atherosclerotic lesions [66], highlighting the need for characterization and standardization of the active compounds of propolis.

MicroRNAs (miRNAs) involved in the development or attenuation of atherosclerotic plaques in LDLr-/- mice were shown to be modulated by propolis [67]. Propolis upregulated the expression of miR-181a, miR-106a, and miR-20b, which correlated with the inhibition of VEGFA and hypoxia-inducible factor-1 (Hif1a) expression [67]. VEGFA is one of the main pro-angiogenic factors in atherosclerotic lesions and Hif1a is expressed in the necrotic nucleus of the atheroma [67-69]. Propolis prevented left ventricular hypertrophy $(\mathrm{LVH})$, the formation of atherosclerotic lesions, arterial and ventricular inflammation, and CD40L expression in LDLr-/- mice [70]. Propolis also increased the serum HDL-c level in the LDLr-/- mice [70]. Fang et al. (2013) demonstrated that ethanolic extract of propolis reduced total cholesterol, triglycerides, and non-HDL-C by $21 \%-32 \%$ compared to control in ApoE (ApoE-/-) knockout mice [71]. Propolis also reduced the expression of pro-inflammatory cytokines, IL-6 and IL-17, and vasoconstrictor peptide endothelin. More importantly, propolis reduced the formation of atherosclerotic lesions in the aortic root and whole aorta [71].

The efficacy of propolis in preventing cardiovascular diseases has also been demonstrated in various human clinical trials. Mujica et al. (2017) carried out a randomized placebo-controlled trial and found that propolis supplementation for 90 days increased HDL-c from $53.9 \pm 11.9$ to $65.8 \pm 16.7 \mathrm{mg} / \mathrm{dL}$. It also increased serum glutathione (GSH) by $175 \%$ and reduced the thiobarbituric acid reactive substance (TBARS) level by $67 \%$ [72]. The serum TBARS level has been shown to be an oxidative stress marker and a strong predictor for cardiovascular events [73]. In addition, Samadi et al. (2017) found that propolis prevented an increase in total cholesterol and LDL-c in type 2 diabetes patients [74]. However, Zakerkish et al. (2019) found that propolis did not reduce LDL-c and total cholesterol but instead increased the serum level of HDL-c in type 2 diabetes patients [75]. Furthermore, Hesami et al. demonstrated that propolis reduced the level of oxidized LDL in type 2 diabetic patients [76]. It appears propolis has a net positive effect in terms of increasing antioxidant status and improving the lipid profile.

\subsection{Hypertension}

Hypertension has been demonstrated to be related to many CVD outcomes including ischemic heart and cerebrovascular diseases. Hypertension was shown to account for $41 \%$ of all disability-adjusted life years (DALYs) in the Global Burden of Disease, Injuries, and Risk Factor Study 2015 (GBD 2015) [77]. More importantly, significant numbers of sufferers are not even aware of the condition. Furthermore, those diagnosed with hypertension are 
frequently given inadequate treatments. Consequently, hypertension will remain as one of major significant public health challenges worldwide regardless of income level [78-80].

Propolis and its phenolic and flavonoid components appear to have beneficial antihypertensive effects. Mishima et al. (2005) demonstrated that various extracts (water and ethanol) of propolis had hypotensive activity in spontaneously hypertensive rats [81]. It was shown that $25 \%$ ethanol extract was more efficacious than $70 \%$ ethanol. They also identified that di- and tri-caffeoylquinic acids were characteristic compounds responsible for the hypotensive effect in the $25 \%$ ethanol extract [81]. In addition, Maruyama et al. (2009) showed that ethanol-eluted fractions of propolis were effective in treating spontaneously hypertensive rats [82]. They isolated and identified four flavonoids, dihydrokaempferide, isosakuranetin, betuletol, and kaempferide, as being the most effective in treating hypertension in the spontaneously hypertensive rats. These flavonoids worked in a dose-dependent manner [82]. Furthermore, propolis was shown to exert an antihypertensive effect in Otsuka Long-Evans Tokushima fatty (OLETF) rats, without affecting the level of aldosterone, suggesting that the effect of propolis is not through endocrine signaling pathways [83].

Several mechanisms of action of the antihypertensive effect of propolis have been suggested. Gogebakan et al. (2012) investigated the antihypertensive effect of propolis ( $30 \%$ ethanol extract) in chronic nitric oxide synthase (NOS)-inhibited rats by $N_{\mathrm{w}}$-nitro-larginine methyl ester (L-NAME) [84]. Propolis extract was shown to reduce the tyrosine hydroxylase activity in the hypertensive L-NAME-treated rats. Tyrosine hydroxylase is a rate-limiting enzyme in the synthesis of catecholamine. Excessive secretion of catecholamine has been shown to promote the over-activation of the sympathetic nervous system, which contributes to hypertension [85]. Propolis also reduced oxidative stress in the hypertensive L-NAME-treated rats by decreasing the expression of malondialdehyde (MDA) [86]. Salmas et al. (2017) investigated the effect of propolis, caffeic acid phenethyl ester (CAPE), a propolis-derived compound, and bee pollen in hypertensive L-NAMEtreated rats. All treated rats were shown to have better biochemical markers associated with oxidation and inflammation, namely, paraoxonase (PON1), oxidative stress index (OSI), total antioxidant status (TAS), total oxidant status (TOS), asymmetric dimethylarginine (ADMA), and nuclear factor kappa B (NF-kB) [87].

High- $\mathrm{NaCl}$ diet-induced hypertension has also been shown to be ameliorated by propolis. Zhou et al. (2020) demonstrated that water-soluble propolis extract reduced the severity of hypertension induced by a high- $\mathrm{NaCl}$ diet in rats [88]. They demonstrated that the protective effect of a water-soluble extract of propolis was through several modes of action, such as the upregulation of antioxidant enzyme catalase (CAT) activity and the reduction in the vascular ROS level. Propolis also reduced inflammatory markers, such as TNF- $\alpha$ and IL-6, and improved endothelial function [88]. Furthermore, Mulyati et al. (2021) investigated the antihypertensive effect of propolis collected from three different regions in Indonesia, namely, Riau Archipelago, Lampung, and South Sulawesi in NaCl-induced hypertensive rats. It was found that all three propolis extracts ameliorated hypertension. However, the antihypertensive effect was not uniform, with propolis from Riau Archipelago and South Sulawesi being more effective compared to propolis from Lampung [89]. This study illustrates the common problem in propolis research where chemical analysis data are often lacking. Consequently, it is difficult to pinpoint the specific chemical compounds or groups of chemical compounds responsible for the biological activity of propolis from different sources and/or geographical locations.

\section{Type 2 Diabetes Mellitus}

Non-insulin-dependent/type 2 diabetes mellitus is characterized by insulin resistance and/or abnormal insulin secretion (hyperinsulinemia), which subsequently cause abnormally high blood glucose levels (hyperglycemia) [90,91]. Chronic hyperglycemia damages and causes the failure of different organs, especially the eyes, kidneys, nerves, heart, and blood vessels $[92,93]$. MetS is a strong predictor for the development of type 2 diabetes [94-96]. 
Propolis ameliorated the symptoms of diabetes in animal models. Water-soluble and ethanolic extracts of propolis were shown to be effective in reducing the increase in blood glucose in alloxan-induced diabetic rats by $18.2 \%-29.5 \%$ in an 8 -week experiment [97]. Ethanolic extract of propolis improved blood glucose control and insulin sensitivity in streptozotocin-induced diabetic rats $[98,99]$. Propolis also had a protective effect on pancreatic $\beta$-cells $[100,101]$. Propolis significantly reduced blood glucose and plasma insulin in Otsuka Long-Evans Tokushima fatty (OLETF) rats (spontaneously diabetic rats) [83]. Propolis extract reduced blood glucose and improved glucose tolerance and insulin sensitivity in $o b / o b$ mice independent of changes in body weight and food intake [102]. It appeared that the blood glucose reduction by propolis was dose-dependent [103].

Furthermore, the efficacy of propolis in reducing pre-diabetic and diabetic symptoms was evident in human clinical trials. Fukuda et al. (2015) investigated the effect of supplementing type 2 diabetes patients with $226.8 \mathrm{mg}$ Brazilian green propolis daily for 8 weeks [104]. They found that the propolis supplement prevented diabetic patients from developing worse blood uric acid and estimated glomerular filtration rate (eGFR). Zhao et al. (2016) demonstrated that propolis improved antioxidant status in type 2 diabetes patients [105]. Serum GSH in the propolis group was increased by $\sim 174 \%$ at the end of an 18-week trial period. A reduction in other oxidative and inflammatory parameters, such as serum carbonyls ( $17 \%$ reduction), TNF- $\alpha$ ( $\sim 21 \%$ reduction), and lactate dehydrogenase activity ( $\sim 8 \%$ reduction), was also observed. However, they noted an increase in IL-6 and IL-1 $\beta$. They also did not find an improvement in glucose metabolism [105]. A propolis-induced increase in antioxidant parameters in type 2 diabetes patients was confirmed by Gao et al. (2018) [106]. They found that after 18 weeks of propolis supplementation, serum GSH was increased by $\sim 236 \%$ in the propolis group when compared to the placebo group [106].

El-Sharkawy et al. (2016) found that $400 \mathrm{mg}$ daily propolis supplementation for 6 months significantly improved clinical parameters of type 2 diabetes patients. HbA1c was reduced by $\sim 11.0 \%$ after 6 months. A similar trend was observed in fasting blood glucose. In addition, serum $\mathrm{N}^{€}$-(carboxymethyl) lysine (CML) was reduced by $\sim 17 \%$ after 6 months [107]. They also found significant improvement in periodontal status in the propolis group patients [107]. Samadi et al. (2017) found that $900 \mathrm{mg} /$ day of propolis consumption for 12 weeks reduced fasting blood glucose (by 12\%) and HbA1c (by 9\%) in type 2 diabetes patients [74]. Furthermore, Zakerkish et al. (2019) investigated the therapeutic benefit of supplementing type 2 diabetes patients with $1000 \mathrm{mg}$ propolis/day for 12 weeks [75]. Propolis significantly improved glucose metabolism and reduced clinical parameters. Propolis reduced serum levels of $\mathrm{HbA} 1 \mathrm{c}$ by $\sim 11 \%$, insulin by $46 \%$, homeostasis model assessment of insulin resistance (HOMA-IR) by $\sim 39 \%$, homeostasis model assessment of $\beta$-cell function (HOMA- $\beta$ ) by $42 \%$, and serum TNF- $\alpha$ by $\sim 30 \%$. Propolis also prevented an increase in $2 \mathrm{~h}$ postprandial blood glucose and high-sensitivity C-reactive protein (hs-CRP) level throughout the trial period [75].

\section{Chronic Kidney Disease}

Studies have shown a strong association of MetS with the development and severity of renal dysfunction and chronic kidney disease (CKD) [108-110]. MetS patients have a several-fold higher risk of developing CKD and it is often shown that renal dysfunction manifests earlier than diabetes in MetS patients [111]. Patients with MetS often suffer from hyperhomocysteinemia, hyperuricemia, lower glomerular filtration rate (GFR), and increased albumin excretion [112,113].

Propolis has been shown to have renal protective properties in animal models. Propolis significantly reduced malondialdehyde (MDA) and increased antioxidant parameters, such as glutathione (GSH), superoxide dismutase (SOD) and catalase (CAT) activities, in renal tissue of streptozotocin-induced diabetic rats $[103,114]$. Propolis also maintained the antioxidant parameters of carbon tetrachloride $\left(\mathrm{CCl}_{4}\right)^{-}$, diatrizoate-, and $\mathrm{N}_{\mathrm{W}}$-nitro-l-arginine methyl ester (L-NAME)-induced oxidative-stressed in murine renal tissues [115-118]. The 
antioxidant properties were dose-dependent and correlated to the polyphenol contents of the propolis extract $[103,115]$.

Propolis has a protective effect on the membrane integrity of renal tissue. Bhadauria (2012) showed that $\mathrm{CCl}_{4}$-damaged murine renal tissue treated with propolis retained better kidney histoarchitecture, less glomerulus swelling, and more uniform space between the glomerulus and capsule wall, when compared to $\mathrm{CCl}_{4}$-damaged murine renal tissue without propolis treatment [116]. The activity of renal membrane-bound enzymes such as adenosine triphosphatase (ATPase) and alkaline phosphatases (ACPase and ALPase) were considerably restored [116]. Propolis maintained the thickness of the glomerular basement membrane in renal tissues of diabetic rats [114]. Untreated diabetic rats had a significant increase in glomerular basement membrane thickness [114]. Propolis also reduced the $\mathrm{CCl}_{4}$-induced apoptosis of renal cells by downregulating the caspase-9 gene and upregulating Bcl-2 gene expression [119].

Furthermore, propolis attenuated methotrexate-induced renal injury [120]. Propolis treatment following methotrexate reduced the rate of apoptosis of renal cells and the degradation of renal morphology, compared to untreated controls [120]. Propolis also had a protective effect on gentamicin-induced renal injury. Propolis significantly reduced gentamicin-induced blood urea nitrogen levels, tubular injury, collagen and reticular deposition, and apoptosis of renal cells [121].

Propolis ameliorated proteinuria, serum creatinine retention, glomerulosclerosis, renal macrophage infiltration, and oxidative stress in 5/6 renal ablated rats (Nx) [122]. Propolis also appears to have a protective role in acute kidney injury. Propolis protected the kidney against ischemic-reperfusion acute renal injury by reducing oxidative stress and upregulating endothelial nitric oxide synthase and heme-oxygenase [123]. Histological analysis showed that propolis-treated renal tissue after ischemic-reperfusion had a significantly lower tubular necrosis score [123]. Propolis also inhibited pro-inflammatory signaling pathways, namely, SMAD 2/3-dependent and SMAD-independent JNK/ERK activation in the signaling cascades of TGF- $\beta$ family, that have been implicated in the development of tubulointerstitial fibrosis in advanced chronic kidney disease in animal models [124].

The effect of propolis in ameliorating kidney disease was evident in human clinical trials. Silveira et al. (2019) demonstrated that the consumption of $500 \mathrm{mg} /$ day of standardized propolis extract significantly reduced proteinuria and the urinary level of monocyte chemoattractant protein-1 (MCP-1), an inflammation marker, in a randomized, doubleblind, placebo-controlled trial in patients with chronic kidney disease [125]. It was found that at the end of the trial period (12 months), proteinuria was significantly lower in the propolis arm, $695 \mathrm{mg} / 24 \mathrm{~h}$, compared to $1403 \mathrm{mg} / 24 \mathrm{~h}$ in the placebo arm. Urinary MCP-1 was also reduced in the propolis arm (58 pg/mg creatinine) compared to the placebo arm (98 pg/mg creatinine) [125]. The same group also showed that propolis was effective in reducing high-sensitivity C-reactive protein (hs-CRP) in hemodialysis patients [126]. Both studies demonstrated that propolis was safe for patients with kidney disease and no adverse events were recorded $[125,126]$.

\section{Non-Alcoholic Fatty Liver Disease (NAFLD)}

NAFLD is the major chronic liver disease in the world and represents the hepatic symptom of MetS [127,128]. NAFLD affects one in four adults and is expected to increase annually in parallel with the increase in MetS prevalence [129]. NAFLD is defined as the appearance of hepatic steatosis with the absence of causes for secondary hepatic fat accumulation, such as excessive alcohol consumption, use of steatogenic prescriptions, or any hereditary disorder [130]. NAFLD is then further categorized into two types; nonalcoholic fatty liver (NAFL) and non-alcoholic steatohepatitis (NASH) [130]. NAFL is diagnosed by the presence of hepatic steatosis without the ballooning of the hepatocytes, whereas NASH is defined by the evidence of hepatic steatosis and inflammation (hepatocyte ballooning) with or without the presence of fibrosis [130]. 
The hepatoprotective properties of propolis appear to be through antioxidant and anti-inflammatory pathways. Propolis and its polyphenols were shown to protect cultured hepatocytes from palmitic acid-induced lipotoxicity [131]. Propolis prevented palmitic acid toxicity of HepG2 cells by maintaining energy provision and inhibiting apoptosis. It also increased the antioxidant capacity of cells by upregulating the superoxide dismutase level and antioxidant gene expressions, such as GSTA1, TXNRD1, NQO-1, HO-1, and Nrf2, while reducing the expression of inflammatory genes of TNF- $\alpha$ and IL-8 [131]. Propolis-derived flavonoids, pinocembrin, galangin, and chrysin, prevented HepG2 cell injury by inhibiting ERK1/2-AHR-CYP1A1 signaling pathways [132]. ERK signaling pathways have been shown to be significant in the formation of liver fibrosis [133].

Propolis attenuated liver damage in an experimental model of diabetes and NAFLD in mice. Propolis reduced the level of alkaline phosphatase (ALP), alanine aminotransferase (ALT), aspartate aminotransferase (AST), lactate dehydrogenase (LDH), gamma-glutamyl transferase (GGT), and malondialdehyde in diabetic mice [134-136] Elevated liver enzymes have been shown to be strongly associated with the severity of liver disease [137]. Conversely, propolis increased the protective antioxidant status, upregulated antioxidant enzymes, namely, superoxide dismutase (SOD), catalase (CAT), glutathione peroxidase (GPx), glutathione-S-transferase (GST), and glutathione reductase (GR), and increased the glutathione level and hepatic total antioxidant capacity of diabetic mice [134-136]. Histological assessment also showed that propolis attenuated liver damage caused by diabetes. Propolis-treated diabetic mice had fewer vacuolized cells, a lesser degree of vacuolization, and less inflammation and infiltration of immune cells [134-136].

A similar trend was shown in NAFLD mice; propolis (and its component chrysin) ameliorated the symptoms by reducing AST, ALT, ALP, GGT, liver triglycerides, liver cholesterol, liver free fatty acids, and liver advanced glycation end products $[138,139]$. Propolis also lowers pro-inflammatory cytokines, TNF- $\alpha$ and IL-6, in NAFLD liver tissue $[138,139]$. Chrysin was shown to inhibit the expression of the SREBP-1c gene and upregulate the PPAR- $\alpha$ gene [139]. SREBP-1c plays an important role in the development of NAFLD, whereas PPAR- $\alpha$ directly inhibits the pro-inflammatory signaling pathways [140,141].

Even though the majority of the animal studies exhibited a hepatoprotective effect of propolis, Samie-Rad et al. (2014) demonstrated liver toxicity when very high doses (2000-8000 mg/kg) of propolis were given to mice [142]. The histopathological changes were dose-dependent and included central venous dilatation, steatosis, confluent necrosis, apoptosis, and focal necroinflammation [142]. However, the dose in this study was in the range of 10-40-fold that of the doses in the positive studies previously mentioned.

The hepatoprotective effect of propolis has been demonstrated in human clinical trials. Soleimani et al. (2020) demonstrated that propolis supplementation of $250 \mathrm{mg}$ twice daily for 4 months had a beneficial effect among NAFLD patients [143]. A significant improvement of hepatic steatosis was evident in the treatment group compared to the placebo group. Propolis attenuated liver stiffness in the treatment group, whereas liver stiffness increased in the placebo arm. Propolis also reduced high-sensitivity C-reactive protein (hs-CRP) [143].

\section{Alzheimer's Disease (AD)}

Alzheimer's disease (AD) is characterized by the presence of amyloid plaques and intracellular neurofibrillary tangles (phosphorylated tau proteins). AD is the most common form of dementia and MetS has been shown to be highly correlated with the development of AD [144,145]. The elevated level of advanced glycation end products (AGEs) associated with hyperglycemia and hyperinsulinemia in MetS has been shown to promote the aggregation of $\beta$-amyloid $(A \beta)$ and glycation and phosphorylation of tau proteins [146-148]. An increased level of oxidative stress in MetS damages mitochondria and promotes the development of AD [149,150]. An increased expression of pro-inflammatory cytokines (associated with MetS), such as TNF- $\alpha$ and IL-6, plays a significant role in the neuroinflammation and neurodegeneration associated with AD [9,151,152]. 
Antioxidant and anti-inflammatory properties of propolis play a major role in its neuroprotective capacity. Propolis protected microglia from hypoxia-induced inflammation and cytotoxicity by inhibiting nuclear factor kappa B (NF-kB) activation through the reduction of the expression of several key pro-inflammatory cytokines; IL-1 $\beta$, IL-6, and TNF- $\alpha[153,154]$. Caffeic acid phenethyl ester (CAPE), a propolis-derived compound, protected microglia by reducing the expression of neurotoxic factors iNOS and COX-2, and inflammatory cytokines IL- 6 and IL- $1 \beta$. Conversely, CAPE upregulated the expression of neuroprotective factor hemeoxygenase (HO)-1 and neurotrophic factor erythropoietin (EPO) in microglia [155].

Propolis also protected neurons from oxidative damage caused by $\mathrm{H}_{2} \mathrm{O}_{2}$ [156]. Propolis prevented the loss of cell viability by $\mathrm{H}_{2} \mathrm{O}_{2}$ and, more importantly, reversed the inhibition of brain-derived neurotrophic factor (BDNF)-induced Arc expression caused by A $\beta$ and IL-1 $\beta$. Propolis also induced the expression of BDNF mRNA and Arc mRNA [156]. BDNF and Arc are crucial in maintaining synaptic efficacy and plasticity and cognitive function $[157,158]$.

The neuroprotective effect of propolis was demonstrated in various animal studies. Naware et al. (2017) showed that propolis reversed the negative effect of $\beta$-amyloidinduced cognitive impairment in mice. They found that propolis attenuated the damaging effect of $\beta$-amyloid by increasing the activity of SOD and CAT, and GSH level, while reducing maloaldehyde level [159]. The neuroprotective effect of propolis by restoring the antioxidant system was also shown by Bazmandegan et al. (2017) [160]. Furthermore, the neuroprotective effect of propolis was also demonstrated in its ability to increase the level of catecholamines, norepinephrine, dopamine, and 5-hydroxy tryptamine, and reduce the activity of acetylcholinesterase [159].

In addition, individual propolis-derived compounds exert neuroprotective properties by activating different pathways. Cadmium (Cd)-induced neurotoxicity and neurodegeneration was attenuated by CAPE in mice [161]. CAPE increased the survival rate of $\mathrm{CdCl}_{2}$-damaged neurons and reduced $\mathrm{CdCl}_{2}$-induced apoptosis. CAPE reduced the accumulation of $\mathrm{A} \beta$ and phosphorylated tau (p-tau) protein, and inhibited the expression of inflammatory markers such as TLR4, IL-6, IL1- $\beta$, and TNF- $\alpha$ [161]. In addition, chrysin exerts a neuroprotective mechanism by inhibiting NF- $\mathrm{KB}$ activation through a separate mechanism: upregulation of the A20 enzyme [154]. The A20 enzyme is a ubiquitin-editing enzyme that is crucial in maintaining the homeostasis of the central nervous system by regulating NF- $\mathrm{kB}$ signaling and its pro-inflammatory cytokines in microglia, neurons, and astrocytes [162].

Zhu et al. (2018) demonstrated that propolis was beneficial in preventing cognitive decline to mild cognitive impairment in elderly people that lived at a high altitude in a 2-year trial period [163]. The placebo group showed a decline in the Mini-Mental State Examination (MMSE) over the trial period, 26.17 to 23.87, whereas the propolis group showed an upward trend from 26.00 to 28.19. The MMSE scores correlated with the serum pro-inflammatory cytokines of the participants. Over the trial period, the serum level of IL-1 $\beta$, IL-6, and TNF- $\alpha$ increased in the placebo arm and decreased in the propolis arm. The placebo arm showed an increase in serum IL- $1 \beta$, IL- 6 , and TNF- $\alpha$ by $\sim 182 \%, 155 \%$, and $62 \%$, respectively, whereas the propolis arm showed a decrease in serum IL- $1 \beta$, IL-6, and TNF- $\alpha$ by $~ 58 \%, 43 \%$, and $50 \%$, respectively, over the 24 -month trial period [163]. This confirms the importance of the anti-inflammatory action of propolis in its neuroprotective capacity. Table 1 summarizes the potential therapeutic uses of propolis in MetS and its chronic diseases. 
Table 1. Summary of various in vitro, in vivo, and human clinical trials with regard to the therapeutic uses of propolis in MetS and its associated chronic diseases.

\begin{tabular}{|c|c|c|c|}
\hline Diseases & Types of Study & Measured Outcome & References \\
\hline $\begin{array}{c}\text { Cardiovascular diseases } \\
\text { (CVDs) }\end{array}$ & in vitro and in vivo & $\begin{array}{l}\text { Reduction in the triglyceride } \\
\text { and LDL level, LDL oxidation, } \\
\text { platelet aggregation, and } \\
\text { expression of atherogenic } \\
\text { growth factors and } \\
\text { immune-mediated } \\
\text { inflammation. }\end{array}$ & [62-71] \\
\hline Atherosclerosis & human clinical trials & $\begin{array}{l}\text { Increase in HDL-c } \\
\text { concentration and antioxidant } \\
\text { status. }\end{array}$ & [72-76] \\
\hline Hypertension & in vivo & $\begin{array}{l}\text { Reduction in hypertension, } \\
\text { oxidative stress, inflammatory } \\
\text { markers, and increase in } \\
\text { antioxidant status. }\end{array}$ & [81-89] \\
\hline \multirow[t]{2}{*}{ Type 2 diabetes mellitus } & in vivo & $\begin{array}{l}\text { Improvement in blood } \\
\text { glucose metabolism, insulin } \\
\text { sensitivity, and antioxidant } \\
\text { status. }\end{array}$ & [97-103] \\
\hline & human clinical trials & $\begin{array}{l}\text { Improvement in blood } \\
\text { glucose metabolism, insulin } \\
\text { sensitivity, antioxidant status, } \\
\text { periodontal status, and } \\
\text { reduction in inflammatory } \\
\text { markers. }\end{array}$ & {$[74,75,104-107]$} \\
\hline \multirow[t]{2}{*}{ Chronic kidney disease } & in vitro and in vivo & $\begin{array}{l}\text { Reduction in inflammatory } \\
\text { markers and fibrosis. } \\
\text { Improvement in antioxidant } \\
\text { status and renal function. }\end{array}$ & {$[103,114-124]$} \\
\hline & human clinical trials & $\begin{array}{l}\text { Reduction in proteinuria, } \\
\text { oxidative stress, and } \\
\text { inflammatory markers. }\end{array}$ & {$[125,126]$} \\
\hline \multirow[t]{2}{*}{$\begin{array}{l}\text { Non-alcoholic fatty liver } \\
\text { disease }\end{array}$} & in-vitro and in-vivo & $\begin{array}{l}\text { Reduction in inflammatory } \\
\text { markers and hepatic steatosis } \\
\text { severity. Improvement in } \\
\text { antioxidant status. }\end{array}$ & [131-142] \\
\hline & human clinical trials & $\begin{array}{l}\text { Reduction in hepatic steatosis } \\
\text { severity and inflammatory } \\
\text { markers. }\end{array}$ & [143] \\
\hline \multirow[t]{2}{*}{ Alzheimer's disease } & in vitro and in vivo & $\begin{array}{l}\text { Reduction in the } \mathrm{A} \beta \text { and tau } \\
\text { accumulation, and } \\
\text { inflammatory markers. } \\
\text { Improvement in antioxidant } \\
\text { status. }\end{array}$ & [153-162] \\
\hline & human clinical trials & $\begin{array}{l}\text { Improvement in cognitive } \\
\text { ability and reduction in } \\
\text { inflammatory markers. }\end{array}$ & [163] \\
\hline
\end{tabular}

\section{Discussion}

MetS and its associated chronic diseases appear to have common denominators, namely, chronic inflammation and increased oxidative stress. Inflammatory pathways such as NF- $\mathrm{kB}$, Jun N-terminal kinase (JNK), and inflammasomes have been shown to play a significant role in the development of MetS pathophysiology [164-168]. Propolis has been 
demonstrated to modulate the inflammatory signaling pathways. CAPE, a propolis-derived compound, completely inhibited the TNF activation of the NF- $\mathrm{KB}$ signaling pathway. CAPE also prevents the nuclear translocation of the $\mathrm{p} 65$ subunit of NF- $\mathrm{B}$ [169]. In addition, CAPE was shown to inhibit inducible nitric oxide synthase (iNOS), an important inflammatory enzyme, by directly modulating the NF- $\mathrm{BB}$ signaling pathway [170]. CAPE inhibits the transcription and synthesis of IL-2, an important NF- $\mathrm{kB}$-promoting cytokine [171]. CAPE is also effective in ameliorating the calcification in human aortic valve interstitial cells by inhibiting the AKT/NF-кB/NLRP3 inflammasome pathway [172].

In addition, propolis downregulates the expression of pro-inflammatory cytokines, such as TNF- $\alpha$, IL-1 $\beta$, IL-4, IL-6, and IL-18 [173-175]. Propolis-derived compounds such as artepillin $C$, chrysin, $3^{\prime}$, 4' -dihydroxy-4-methoxydalbergione, 4-methoxydalbergion, and cearoin are efficacious in inhibiting NF- $\mathrm{KB}$ and JNK signaling pathways [176-178]. Furthermore, propolis ameliorates adiponectin downregulation in adipocytes by inhibiting the TNF- $\alpha$-induced JNK signaling pathway [179]. The correlation of lowered adiponectin and increased pro-inflammatory cytokine level was observed in MetS patients [180]. Propolis supplementation was efficacious in reducing various pro-inflammatory cytokines in chronic inflammation and MetS, namely, C-reactive protein (CRP), TNF- $\alpha$, and IL-6 in human clinical trials [181,182].

Metabolic syndrome increases the production of AGEs and reactive oxygen species (ROS) [183-186]. The combination of these pathophysiological changes causes insulin resistance, metabolic dysfunction, oxidative stress, and mitochondrial dysfunction, leading to cell death [187-190]. AGEs are a group of modified proteins, lipids, or nucleic acids, of which their amino groups react with the carbonyl group of a reducing sugar, and subsequently become glycated and/or oxidized [191]. The interaction of AGEs with their receptor (RAGE) induces ROS production and activates the undesirable inflammation signaling pathways, such as NF-kB [192].

Propolis and its derived compounds have anti-AGE properties. Pinocembrin, a propolisderived flavanone, inhibits the expression of the receptors for advanced glycation end products (RAGE) [193]. Propolis also directly reduces the in vitro formation of AGEs with its derived compounds, such as pinobanksin-3-acetate, 2-acetyl-1,3-dicoumaroylglycerol, pinobanksin, prenyl caffeate, and pinobanksin-5-methyl ether, being the most effective [194]. In addition, propolis in the form of nanoparticles was shown to inhibit the glycation and fructation of hemoglobin by glucose and fructose, respectively [195]. Propolis appears to have two main pathways in inhibiting AGE formation: by trapping the dicarbonyl intermediates (pinobanksin derivatives) and by activating antioxidant mechanisms (caffeic acid derivatives) [196].

Propolis exerts antioxidant properties by scavenging ROS and activating cellular antioxidant systems. Propolis extracts from various regions have been demonstrated to have radical-scavenging properties. The activity correlates with the polyphenol and flavonoid content [89,197-200]. Moreover, propolis and its phenolic constituents promote endogenous cellular antioxidant systems through various mechanisms. Propolis increases the expression of antioxidant enzymes, such as CAT, GPx, GR, GST, and SOD, and endogenous GSH [103,114,134-136]. Propolis also activates the important nuclear factor E2-related factor 2 (Nrf2) antioxidant signaling pathway [201,202].

Figure 1 summarizes the mechanisms of action of propolis in ameliorating MetS symptoms. Sedentary lifestyle and overnutrition cause the development of MetS. One of the MetS hallmarks is the increase in blood glucose, which promotes the formation of AGEs. AGEs subsequently bind to their respective receptors (RAGEs). These interactions promote the formation of ROS. MetS also simultaneously induces the formation of ROS independent of the AGE-RAGE interactions. The increased ROS level consequently promotes the inflammatory signaling cascades through the upregulation of NF- $\mathrm{B}, \mathrm{ERK}, \mathrm{JNK}$, and NLRP3 inflammasome signaling pathways. The activation of these inflammatory pathways increases the level of circulating pro-inflammatory cytokines, such as C-reactive protein (CRP), TNF- $\alpha$, and IL-6. The combination of increased oxidative stress and chronic inflam- 
matory conditions causes cellular, endothelial, and vascular dysregulation and dysfunction, which manifest in the pathophysiology of MetS chronic diseases. Propolis appears to inhibit the development and manifestation of MetS by at least three mechanisms of action: the inhibition of the expression of AGE and RAGE and their interactions, the downregulation of pro-inflammatory signaling cascades, and the upregulation of the cellular antioxidant systems.

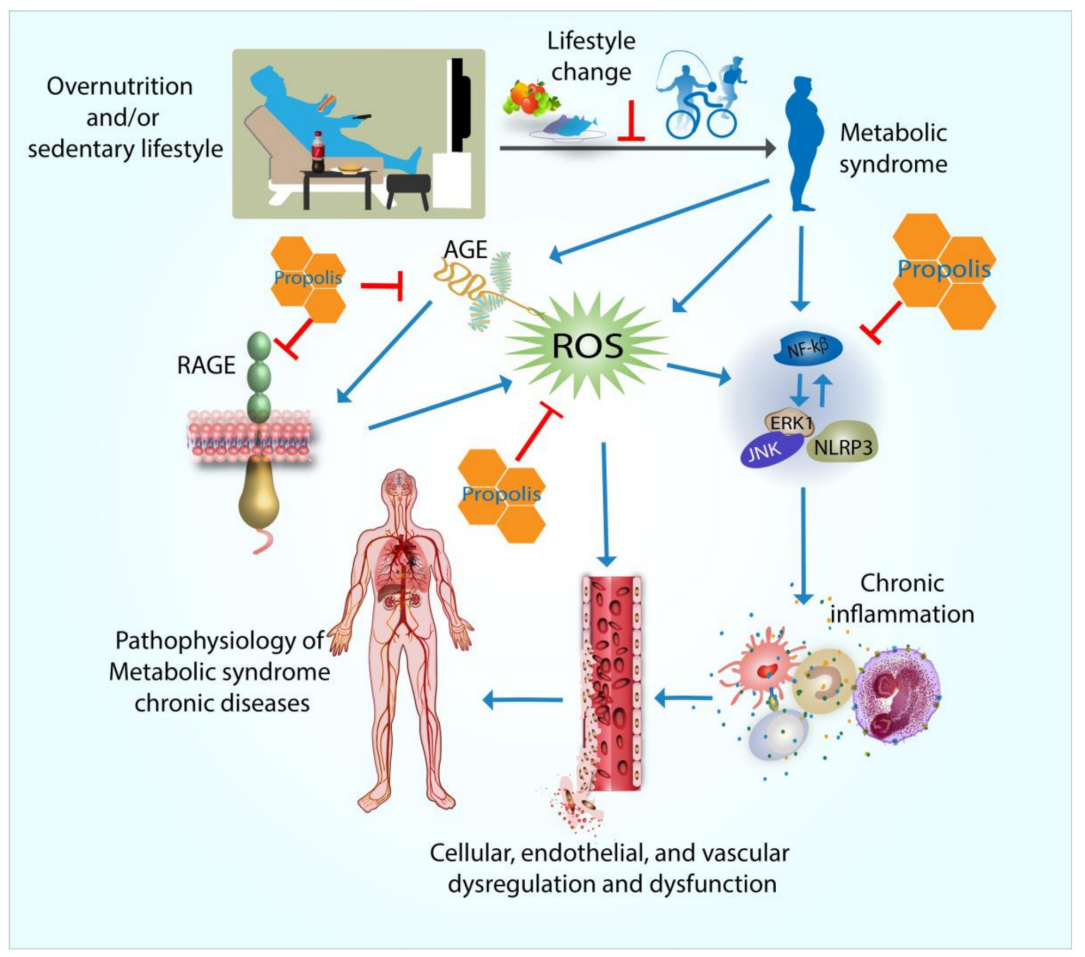

Figure 1. The mechanisms of action of propolis in ameliorating metabolic syndrome (MetS). MetS is induced by overnutrition and/or sedentary lifestyle. The first step of preventing MetS from developing is lifestyle modification. Once developed, MetS induces the formation of advanced glycation end products (AGEs), oxidative stress in the form of increased level of reactive of oxygen species (ROS), and chronic inflammation. AGEs bind to their receptors (RAGEs) and consequently induce further ROS production. ROS promote cellular dysfunction and dysregulation by either directly affecting the cells or inducing chronic inflammation. Chronic inflammation manifests in increased levels of pro-inflammatory cytokines through the upregulation of NF- $\mathrm{BB}, \mathrm{ERK}, \mathrm{JNK}$, and NLRP3 inflammasome signaling pathways. Chronic and prolonged cellular, endothelial, and vascular dysfunction and dysregulation from increased AGEs, ROS, and inflammation result in the pathophysiology of MetS and its diseases. Propolis with its antioxidant and anti-inflammatory properties acts by directly inhibiting AGEs and RAGEs, ROS production, and the inflammation signaling pathways.

One of the main issues in propolis research and its eventual use as a therapeutic is the significant variability of its chemical composition. The chemical composition of propolis is dependent upon many variables. Several studies have shown the significant differences in chemical compositions and hence the differences in biological activities by the propolis collected by different bee species [203,204]. Geographical location also plays a significant role in the propolis chemical compositions. Comprehensive reviews by Rivera-Yanez et al. (2021) and Dezmirean et al. (2021) showed the variety of chemical compounds in propolis from around the world $[205,206]$. The differences in chemical composition are also evident in the propolis obtained from the same genus of plants but from different geographical locations [206]. 
In addition, the biological activities of propolis appear to be affected by seasonal variation. For example, Valencia et al. (2017) demonstrated that propolis obtained in different seasons from the Sonoran region (Mexico) had different chemical compositions and different antiproliferative activities against the the B-cell lymphoma cancer cell line M12.C3.F6 [207]. The antiproliferative activity $\left(\mathrm{IC}_{50}\right)$ ranged from $11.6 \mu \mathrm{g} / \mathrm{mL}$ to $54.5 \mu \mathrm{g} / \mathrm{mL}$, from spring to autumn, respectively [207]. Reguiera et al. (2017) also noted seasonal variation in the antimicrobial effect of Brazilian red propolis against Escherichia coli and Staphylococcus aureus, but not Pseudomonas aeruginosa [208]. Furthermore, the solvents used in the extract preparation play a significant role in determining the biological activities of propolis. As an example, Mishima et al. (2005) showed that $25 \%$ ethanol extract of propolis was more efficacious in terms of antihypertensive activity compared to $70 \%$ ethanol extract [81]. We propose that every study investigating the biological activities of propolis should be accompanied by chemical analysis data and geographical indications of the propolis source. The adoption of these parameters will significantly increase the reproducibility rate and the quality of propolis research going forward. A higher reproducibility rate and research quality will expedite the translation from laboratory benches to clinical uses of propolis.

\section{Conclusions}

Propolis is a sticky mixture of plant resins collected by the bees mixed with digestive enzymes of the bees, and also sometimes beeswax, that has strong antimicrobial properties that help protect the bee colony. Large numbers of in vitro, animal, and, more importantly, human clinical trials have demonstrated the safety and efficacy of propolis. The present review study illustrates the potential use of propolis in ameliorating MetS and its diseases. The therapeutic benefits of propolis in MetS appear to be associated with its potent antiinflammatory and antioxidant properties. One of the main drawbacks of propolis as a therapeutic involves the lack of standardization. However, it can promptly be overcome by the chemical fingerprinting of its phenolics, flavonoids, terpenoids, and other bioactive compounds. The standardization (or the lack thereof) issues can also be overcome by assigning geographical indications.

Author Contributions: Conceptualization, F.Z; writing—review and editing, F.Z., M.R., K.K., K.C., J.F. and C.O.P. All authors have read and agreed to the published version of the manuscript.

Funding: This research received no external funding and the APC was funded by Kebun Efi.

Acknowledgments: We are thankful to Fuad Bahram for the production of Figure 1 and the graphical abstract.

Conflicts of Interest: Kebun Efi produces propolis tinctures from Indonesian stingless bees. The Apiceutical Research Centre is a not-for-profit organization with the aims to promote and develop sustainable beekeeping and beehive-derived medicines. All other authors declare no competing financial interests and no conflict of interest.

\section{References}

1. The Top 10 Causes of Death. WHO Global Health Estimates. 2020. Available online: https:/ /www.who.int/news-room/factsheets/detail/the-top-10-causes-of-death (accessed on 20 December 2020).

2. Ford, E.S.; Li, C.; Sattar, N. Metabolic syndrome and incident diabetes. Diabetes Care 2008, 31, 1898-1904. [CrossRef] [PubMed]

3. Mortillo, S.; Filion, K.B.; Genest, J.; Joseph, L.; Pilote, L.; Poirier, P.; Eisenberg, M.J. The metabolic syndrome and cardiovascular risk: A systematic review and meta-analysis. J. Am. Coll. Cardiol. 2010, 56, 1113. [CrossRef] [PubMed]

4. Wang, J.; Ruotsalainen, S.; Moilanen, L.; Lepistö, P.; Laakso, M.; Kuusisto, J. The Metabolic Syndrome Predicts Incident Stroke. Stroke 2008, 39, 1078-1083. [CrossRef]

5. Boden-Albala, B.; Sacco, R.L.; Lee, H.-S.; Grahame-Clarke, C.; Rundek, T.; Elkind, M.V.; Wright, C.; Giardina, E.-G.V.; DiTullio, M.R.; Homma, S.; et al. Metabolic Syndrome and Ischemic Stroke Risk. Stroke 2008, 39, 30-35. [CrossRef] [PubMed]

6. Chen, H.; Zheng, X.; Zong, X.; Li, Z.; Li, N.; Hur, J.; Fritz, C.D.L.; Chapman, W., Jr.; Nickel, K.B.; Tipping, A.; et al. Metabolic syndrome, metabolic comorbid conditions and risk of early-onset colorectal cancer. Gut 2020. [CrossRef]

7. De Sousa Rodrigues, M.E.; Houser, M.C.; Walker, D.I.; Jones, D.P.; Chang, J.; Barnum, C.J.; Tansey, M.G. Targeting soluble tumor necrosis factor as a potential intervention to lower risk for late-onset Alzheimer's disease associated with obesity, metabolic syndrome, and type 2 diabetes. Alzheimer's Res. Ther. 2019, 12, 1. [CrossRef] 
8. Borshchev, Y.Y.; Uspensky, Y.P.; Galagudza, M.M. Pathogenetic pathways of cognitive dysfunction and dementia in metabolic syndrome. Life Sci. 2019, 237. [CrossRef]

9. Rojas-Gutierrez, E.; Muñoz-Arenas, G.; Treviño, S.; Espinosa, B.; Chavez, R.; Rojas, K.; Flores, G.; Díaz, A.; Guevara, J. Alzheimer's disease and metabolic syndrome: A link from oxidative stress and inflammation to neurodegeneration. Synapse 2017, 71, e21990. [CrossRef]

10. Kwan, B.C.H.; Beddhu, S. Metabolic syndrome and chronic kidney disease. Minerva Urol. Nefrol. 2006, 58, 1-12.

11. Scholze, J.; Alegria, E.; Ferri, C.; Langham, S.; Stevens, W.; Jeffries, D.; Uhl-Hochgraeber, K. Epidemiological and economic burden of metabolic syndrome and its consequences in patients with hypertension in Germany, Spain and Italy; A prevalence-based model. BMC Public Health 2010, 10, 529. [CrossRef]

12. Xie, J.; Zu, Y.; Alkhatib, A.; Pham, T.T.; Gill, F.; Jang, A.; Radosta, S.; Chaaya, G.; Myers, L.; Zifodya, J.S.; et al. Metabolic Syndrome and COVID-19 Mortality Among Adult Black Patients in New Orleans. Diabetes Care 2020, dc201714. [CrossRef] [PubMed]

13. Dietz, W.; Santos-Burgoa, C. Obesity and its Implications for COVID-19 Mortality. Obesity 2020, 28, 1005. [CrossRef] [PubMed]

14. Mauvais-Jarvis, F. Aging, male sex, obesity, and metabolic inflammation create the perfect storm for COVID-19. Diabetes 2020, 69, 1857-1863. [CrossRef]

15. McGurnaghan, S.J.; Weir, A.; Bishop, J.; Kennedy, S.; Blackbourn, L.A.K.; McAllister, D.A.; Hutchinson, S.; Caparrotta, T.M.; Mellor, J.; Jeyam, A.; et al. Risks of and risk factors for COVID-19 disease in people with diabetes: A cohort study of the total population of Scotland. Lancet Diabetes Endocrinol. 2020. [CrossRef]

16. G. Saklayen, M. The global epidemic of the metabolic syndrome. Curr. Hypertens. Rep. 2018, 20, 12. [CrossRef]

17. Sigit, F.S.; Tahapary, D.L.; Trompet, S.; Sartono, E.; Willems Van Dijk, K.; Rosendaal, F.R.; De Mutsert, R. The prevalence of metabolic syndrome and its association with body fat distribution in middle-aged individuals from Indonesia and the Netherlands: A cross-sectional analysis of two population-based studies. Diabetol. Metab. Syndr. 2020, 12, 2. [CrossRef] [PubMed]

18. Joshi, P.; Ghosh, K.; Natarajan, V.S.; Mandal, P. Impact of healthcare access and socio-economic conditions on prevalence of metabolic syndrome: Evidence from 2015 brfss. Int. J. Bus. Excell. 2020, 21, 429-443. [CrossRef]

19. Grundy, S.M.; Brewer, H.B.; Cleeman, J.I.; Smith, S.C.; Lenfant, C. Definition of Metabolic Syndrome. Arterioscler. Thromb. Vasc. Biol. 2004, 24, e13-e18. [CrossRef]

20. Alberti, K.G.M.M.; Zimmet, P.; Shaw, J. Metabolic syndrome-A new world-wide definition. A consensus statement from the International Diabetes Federation. Diabet. Med. 2006, 23, 469-480. [CrossRef]

21. Eckel, R.H.; Alberti, K.G.M.M.; Grundy, S.M.; Zimmet, P.Z. The metabolic syndrome. Lancet 2010, 375, 181-183. [CrossRef]

22. Stone, N.J.; Saxon, D. Approach to treatment of the patient with metabolic syndrome: Lifestyle therapy. Am. J. Cardiol. 2005, 96, 15-21. [CrossRef] [PubMed]

23. Bassi, N.; Karagodin, I.; Wang, S.; Vassallo, P.; Priyanath, A.; Massaro, E.; Stone, N. Lifestyle modification for metabolic syndrome: A systematic review. Am. J. Med. 2014, 127, 1242. [CrossRef] [PubMed]

24. Iqbal, S.P.; Ramadas, A.; Fatt, Q.K.; Shin, H.L.; Onn, W.Y.; Kadir, K.A. Relationship of sociodemographic and lifestyle factors and diet habits with metabolic syndrome (MetS) among three ethnic groups of the Malaysian population. PLoS ONE 2020, 15, e0224054. [CrossRef] [PubMed]

25. Aggarwal, B. Targeting inflammation-induced obesity and metabolic diseases by curcumin and other nutraceuticals. Annu. Rev. Nutr. 2010, 30, 173-199. [CrossRef] [PubMed]

26. Davì, G.; Santilli, F.; Patrono, C. Nutraceuticals in diabetes and metabolic syndrome. Cardiovasc. Ther. 2010, 28, 216-226. [CrossRef]

27. Affuso, F. A nutraceutical combination improves insulin sensitivity in patients with metabolic syndrome. World J. Cardiol. 2012, 4, 77. [CrossRef]

28. Mercurio, V.; Pirozzi, F.; Provenzano, S.; Sarnataro, M.; Parrella, P.; Criscuolo, P.; Tocchetti, C.G.; Abete, P.; Petretta, M.; Fazio, S.; et al. A nutraceutical combination improves insulin sensitivity in patients with metabolic syndrome: A randomized, double-blind, placebo-controlled trial. Vascul. Pharmacol. 2015, 75, 63. [CrossRef]

29. Amiot, M.J.; Riva, C.; Vinet, A. Effects of dietary polyphenols on metabolic syndrome features in humans: A systematic review. Obes. Rev. 2016, 17, 573-586. [CrossRef]

30. Sirtori, C.; Pavanello, C.; Calabresi, L.; Ruscica, M. Nutraceutical approaches to metabolic syndrome. Ann. Med. 2017, 49, 678-697. [CrossRef]

31. Isakov, V.A.; Bogdanova, A.A.; Bessonov, V.V.; Sentsova, T.B.; Tutelyan, V.A.; Lin, Y.; Kazlova, V.; Hong, J.; Velliquette, R.A. Effects of multivitamin, multimineral and phytonutrient supplementation on nutrient status and biomarkers of heart health risk in a russian population: A randomized, double blind, placebo controlled study. Nutrients 2018, 10, 120. [CrossRef]

32. Kim, S.W.; Goossens, A.; Libert, C.; Van Immerseel, F.; Staal, J.; Beyaert, R. Phytohormones: Multifunctional nutraceuticals against metabolic syndrome and comorbid diseases. Biochem. Pharmacol. 2020, 175, 113866. [CrossRef] [PubMed]

33. Ghisalberti, E. Propolis: A review. Bee World 1979, 60, 59-84. [CrossRef]

34. Park, Y.K.; Alencar, S.M.; Aguiar, C.L. Botanical origin and chemical composition of Brazilian propolis. J. Agric. Food Chem. 2002, 50, 2502-2506. [CrossRef]

35. Sahinler, N.; Kaftanoglu, O. Natural product propolis: Chemical composition. Nat. Prod. Res. 2005, 19, 183-188. [CrossRef]

36. Salatino, A.; Salatino, M.L.F. Scientific note: Often quoted, but not factual data about propolis composition. Apidologie 2021. [CrossRef]

37. Niu, G.; Johnson, R.M.; Berenbaum, M.R. Toxicity of mycotoxins to honeybees and its amelioration by propolis. Apidologie 2011, 42, 79-87. [CrossRef] 
38. Mao, W.; Schuler, M.A.; Berenbaum, M.R. Honey constituents up-regulate detoxification and immunity genes in the western honey bee Apis mellifera. Proc. Natl. Acad. Sci. USA 2013, 110, 8842-8846. [CrossRef]

39. Yemor, T.; Phiancharoen, M.; Eric Benbow, M.; Suwannapong, G. Effects of stingless bee propolis on Nosema ceranae infected Asian honey bees, Apis cerana. J. Apic. Res. 2015, 54, 468-473. [CrossRef]

40. Borba, R.S.; Klyczek, K.K.; Mogen, K.L.; Spivak, M. Seasonal benefits of a natural propolis envelope to honey bee immunity and colony health. J. Exp. Biol. 2015, 218, 3689-3699. [CrossRef]

41. Saelao, P.; Borba, R.S.; Ricigliano, V.; Spivak, M.; Simone-Finstrom, M. Honeybee microbiome is stabilized in the presence of propolis. Biol. Lett. 2020, 16, 20200003. [CrossRef]

42. Dalenberg, H.; Maes, P.; Mott, B.; Anderson, K.E.; Spivak, M. Propolis envelope promotes beneficial bacteria in the honey bee (Apis mellifera) mouthpart microbiome. Insects 2020, 11, 453. [CrossRef]

43. Kuropatnicki, A.K.; Szliszka, E.; Krol, W. Historical aspects of propolis research in modern times. Evidence-Based Complement. Altern. Med. 2013, 2013, 964149. [CrossRef] [PubMed]

44. Wang, K.; Ping, S.; Huang, S.; Hu, L.; Xuan, H.; Zhang, C.; Hu, F. Molecular mechanisms underlying the in vitro anti-inflammatory effects of a flavonoid-rich ethanol extract from chinese propolis (poplar type). Evid. Based Complement. Altern. Med. 2013, $2013,127672$.

45. Ibrahim, N.; Zakaria, A.J.; Ismail, Z.; Mohd, K.S. Antibacterial and phenolic content of propolis produced by two Malaysian stingless bees, Heterotrigona itama and Geniotrigona thoracica. Int. J. Pharmacogn. Phytochem. Res. 2016, 8, $156-161$.

46. Corrêa, F.R.S.; Schanuel, F.S.; Moura-Nunes, N.; Monte-Alto-Costa, A.; Daleprane, J.B. Brazilian red propolis improves cutaneous wound healing suppressing inflammation-associated transcription factor NFkB. Biomed. Pharmacother. 2017, 86, 162-171. [CrossRef]

47. Zhang, W.; Cai, Y.; Chen, X.; Ji, T.; Sun, L. Optimized extraction based on the terpenoids of Heterotrigona itama propolis and their antioxidative and anti-inflammatory activities. J. Food Biochem. 2020, 44, e13296. [CrossRef] [PubMed]

48. Amalia, E.; Diantini, A.; Subarnas, A. Water-soluble propolis and bee pollen of Trigona spp. From South Sulawesi Indonesia induce apoptosis in the human breast cancer MCF-7 cell line. Oncol. Lett. 2020, 20, 274. [CrossRef]

49. Zulhendri, F.; Felitti, R.; Fearnley, J.; Ravalia, M. The Use of Propolis in Dentistry, Oral Health, and Medicine: A Review. J. Oral Biosci. 2021. [CrossRef] [PubMed]

50. Refaat, H.; Mady, F.M.; Sarhan, H.A.; Rateb, H.S.; Alaaeldin, E. Optimization and evaluation of propolis liposomes as a promising therapeutic approach for COVID-19. Int. J. Pharm. 2021, 592, 120028. [CrossRef]

51. Sahlan, M.; Irdiani, R.; Flamandita, D.; Aditama, R.; Alfarraj, S.; Ansari, M.J.; Khayrani, A.C.; Pratami, D.K.; Lischer, K. Molecular interaction analysis of Sulawesi propolis compounds with SARS-CoV-2 main protease as preliminary study for COVID-19 drug discovery. J. King Saud Univ. Sci. 2021, 33, 101234. [CrossRef]

52. Fiorini, A.C.; Scorza, C.A.; De Almeida, A.C.G.; Fonseca, M.C.M.; Finsterer, J.; Fonseca, F.L.A.; Scorza, F.A. Antiviral activity of brazilian green propolis extract against sars-cov-2 (Severe acute respiratory syndrome-coronavirus 2) infection: Case report and review. Clinics 2021, 76, e2357. [CrossRef]

53. Ross, R. Inflammation or Atherogenesis. N. Engl. J. Med. 1999, 340, 115-126. [CrossRef]

54. Libby, P. Inflammation in atherosclerosis. Arterioscler. Thromb. Vasc. Biol. 2012, 32, 2045-2051. [CrossRef]

55. Malekmohammad, K.; Sewell, R.D.E.; Rafieian-Kopaei, M. Antioxidants and atherosclerosis: Mechanistic aspects. Biomolecules 2019, 9, 301. [CrossRef] [PubMed]

56. Marchio, P.; Guerra-Ojeda, S.; Vila, J.M.; Aldasoro, M.; Victor, V.M.; Mauricio, M.D. Targeting early atherosclerosis: A focus on oxidative stress and inflammation. Oxid. Med. Cell. Longev. 2019, 2019. [CrossRef] [PubMed]

57. Nguyen, M.; Fernando, S.; Schwarz, N.; Tan, J.; Bursill, C.; Psaltis, P. Inflammation as a Therapeutic Target in Atherosclerosis. J. Clin. Med. 2019, 8, 1109. [CrossRef] [PubMed]

58. Varbo, A.; Benn, M.; Tybjærg-Hansen, A.; Jørgensen, A.B.; Frikke-Schmidt, R.; Nordestgaard, B.G. Remnant cholesterol as a causal risk factor for ischemic heart disease. J. Am. Coll. Cardiol. 2013, 61, 427-436. [CrossRef]

59. Balling, M.; Afzal, S.; Varbo, A.; Langsted, A.; Davey Smith, G.; Nordestgaard, B.G. VLDL Cholesterol Accounts for One-Half of the Risk of Myocardial Infarction Associated With apoB-Containing Lipoproteins. J. Am. Coll. Cardiol. 2020, 76, 2725-2735. [CrossRef]

60. Castañer, O.; Pintó, X.; Subirana, I.; Amor, A.J.; Ros, E.; Hernáez, Á.; Martínez-González, M.Á.; Corella, D.; Salas-Salvadó, J.; Estruch, R.; et al. Remnant Cholesterol, Not LDL Cholesterol, Is Associated With Incident Cardiovascular Disease. J. Am. Coll. Cardiol. 2020, 76, 2712-2724. [CrossRef]

61. Meager, A. Cytokine regulation of cellular adhesion molecule expression in inflammation. Cytokine Growth Factor Rev. 1999, 10, 27-39. [CrossRef]

62. Claus, R.; Kinscherf, R.; Gehrke, C.; Bonaterra, G.; Basnet, P.; Metz, J.; Deigner, H.P. Antiapoptotic effects of propolis extract and propol on human macrophages exposed to minimally modified low density lipoprotein. Arzneim. Forsch./Drug Res. 2000, 50, 373-379. [CrossRef]

63. Saavedra, N.; Cuevas, A.; Cavalcante, M.F.; Dörr, F.A.; Saavedra, K.; Zambrano, T.; Abdalla, D.S.P.; Salazar, L.A. Polyphenols from Chilean Propolis and Pinocembrin Reduce MMP-9 Gene Expression and Activity in Activated Macrophages. BioMed Res. Int. 2016, 2016, 6505383. [CrossRef] [PubMed]

64. Galis, Z.S.; Sukhova, G.K.; Lark, M.W.; Libby, P. Increased expression of matrix metalloproteinases and matrix degrading activity in vulnerable regions of human atherosclerotic plaques. J. Clin. Investig. 1994, 94, 2493-2503. [CrossRef] [PubMed]

65. Zhang, Y.X.; Yang, T.T.; Xia, L.; Zhang, W.F.; Wang, J.F.; Wu, Y.P. Inhibitory Effect of Propolis on Platelet Aggregation in Vitro. J. Healthc. Eng. 2017, 2017, 3050895. [CrossRef] 
66. Daleprane, J.B.; Abdalla, D.S. Emerging roles of propolis: Antioxidant, cardioprotective, and antiangiogenic actions. Evid. Based Complement. Altern. Med. 2013, 2013, 175135. [CrossRef] [PubMed]

67. Cuevas, A.; Saavedra, N.; Cavalcante, M.F.; Salazar, L.A.; Abdalla, D.S.P. Identification of microRNAs involved in the modulation of pro-angiogenic factors in atherosclerosis by a polyphenol-rich extract from propolis. Arch. Biochem. Biophys. 2014, 557, 28-35. [CrossRef]

68. Mayumi, I.; Hiroshi, I.; Makiko, U.; Takahiko, N.; Akiko, K.; Ryushi, K.; Kentaro, D.; Yoshihiro, O.; Naohisa, T.; Kazuhiko, T.; et al. Vascular Endothelial Growth Factor (VEGF) Expression in Human Coronary Atherosclerotic Lesions. Circulation 1998, 98, 2108-2116.

69. Pfluecke, C.; Christoph, M.; Ibrahim, K.; Mensch, M.; Barthel, P.; Franke, K.; Wielockx, B.; Strasser, R.H.; Wunderlich, C.; Poitz, D.M. PHD-2 knockout promotes plaque progression via HIF1a and increases expression of MAC-1, PSGL-1 and VLA-4 on monocytes and granulocytes in mice. J. Am. Coll. Cardiol. 2013, 61, E1829. [CrossRef]

70. Silva, D.; Miranda, A.; Silva, D.D.; Angelo, L.; Rosa, B.; Soares, E.; Ramalho, J.; Boriollo, M.; Garcia, J. Propolis and swimming in the prevention of atherogenesis and left ventricular hypertrophy in hypercholesterolemic mice. Braz. J. Biol. 2015, 75, 414-422. [CrossRef]

71. Fang, Y.; Sang, H.; Yuan, N.; Sun, H.; Yao, S.; Wang, J.; Qin, S. Ethanolic extract of propolis inhibits atherosclerosis in ApoEknockout mice. Lipids Health Dis. 2013, 12. [CrossRef]

72. Mujica, V.; Orrego, R.; Pérez, J.; Romero, P.; Ovalle, P.; Zúñiga-Hernández, J.; Arredondo, M.; Leiva, E. The Role of Propolis in Oxidative Stress and Lipid Metabolism: A Randomized Controlled Trial. Evid. Based Complement. Altern. Med. 2017, 2017. [CrossRef]

73. Walter, M.F.; Jacob, R.F.; Jeffers, B.; Ghadanfar, M.M.; Preston, G.M.; Buch, J.; Mason, R.P. Serum levels of thiobarbituric acid reactive substances predict cardiovascular events in patients with stable coronary artery disease: A longitudinal analysis of the PREVENT study. J. Am. Coll. Cardiol. 2004, 44, 1996-2002. [CrossRef]

74. Samadi, N.; Mozaffari-Khosravi, H.; Rahmanian, M.; Askarishahi, M. Effects of bee propolis supplementation on glycemic control, lipid profile and insulin resistance indices in patients with type 2 diabetes: A randomized, double-blind clinical trial. J. Integr. Med. 2017, 15, 124-134. [CrossRef]

75. Zakerkish, M.; Jenabi, M.; Zaeemzadeh, N.; Hemmati, A.A.; Neisi, N. The Effect of Iranian Propolis on Glucose Metabolism, Lipid Profile, Insulin Resistance, Renal Function and Inflammatory Biomarkers in Patients with Type 2 Diabetes Mellitus: A Randomized Double-Blind Clinical Trial. Sci. Rep. 2019, 9. [CrossRef] [PubMed]

76. Hesami, S.; Hashemipour, S.; Shiri-Shahsavar, M.R.; Koushan, Y.; Khadem Haghighian, H. Administration of Iranian Propolis attenuates oxidative stress and blood glucose in type II diabetic patients: A randomized, double-blind, placebo-controlled, clinical trial. Casp. J. Intern. Med. 2019, 10, 48-54.

77. Forouzanfar, M.H.; Afshin, A.; Alexander, L.T.; Biryukov, S.; Brauer, M.; Cercy, K.; Charlson, F.J.; Cohen, A.J.; Dandona, L.; Estep, K.; et al. Global, regional, and national comparative risk assessment of 79 behavioural, environmental and occupational, and metabolic risks or clusters of risks, 1990-2015: A systematic analysis for the Global Burden of Disease Study 2015. Lancet 2016, 388, 1659-1724. [CrossRef]

78. Kearney, P.M.; Whelton, M.; Reynolds, K.; Whelton, P.K.; He, J. Worldwide prevalence of hypertension: A systematic review. J. Hypertens. 2004, 22, 11-19. [CrossRef]

79. Danaei, G.; Ding, E.L.; Mozaffarian, D.; Taylor, B.; Rehm, J.; Murray, C.J.L.; Ezzati, M. The preventable causes of death in the United States: Comparative risk assessment of dietary, lifestyle, and metabolic risk factors. PLoS Med. 2009, 6, e1000058. [CrossRef]

80. Rosanoff, A.; Costello, R.B.; Johnson, G.H. Effectively prescribing oral magnesium therapy for hypertension: A categorized systematic review of 49 clinical trials. Nutrients 2021, 13, 195. [CrossRef]

81. Mishima, S.; Yoshida, C.; Akino, S.; Sakamoto, T. Antihypertensive effects of Brazilian propolis: Identification of caffeoylquinic acids as constituents involved in the hypotension in spontaneously hypertensive rats. Biol. Pharm. Bull. 2005, 28, 1909-1914. [CrossRef]

82. Maruyama, H.; Sumitou, Y.; Sakamoto, T.; Araki, Y.; Hara, H. Antihypertensive effects of flavonoids isolated from Brazilian green propolis in spontaneously hypertensive rats. Biol. Pharm. Bull. 2009, 32, 1244-1250. [CrossRef] [PubMed]

83. Aoi, W.; Hosogi, S.; Niisato, N.; Yokoyama, N.; Hayata, H.; Miyazaki, H.; Kusuzaki, K.; Fukuda, T.; Fukui, M.; Nakamura, N.; et al. Improvement of insulin resistance, blood pressure and interstitial $\mathrm{pH}$ in early developmental stage of insulin resistance in OLETF rats by intake of propolis extracts. Biochem. Biophys. Res. Commun. 2013, 432, 650-653. [CrossRef]

84. Gogebakan, A.; Talas, Z.S.; Ozdemir, I.; Sahna, E. Role of propolis on tyrosine hydroxylase activity and blood pressure in nitric oxide synthase-inhibited hypertensive rats. Clin. Exp. Hypertens. 2012, 34, 424-428. [CrossRef] [PubMed]

85. Lee, Y.H.; Kim, Y.G.; Moon, J.Y.; Kim, J.S.; Jeong, K.H.; Lee, T.W.; Ihm, C.G.; Lee, S.H. Genetic variations of tyrosine hydroxylase in the pathogenesis of hypertension. Electrolyte Blood Press. 2016, 14, 21-26. [CrossRef] [PubMed]

86. Selamoglu Talas, Z. Propolis reduces oxidative stress in l-NAME-induced hypertension rats. Cell Biochem. Funct. 2014, 32, 150-154. [CrossRef]

87. Salmas, R.E.; Gulhan, M.F.; Durdagi, S.; Sahna, E.; Abdullah, H.I.; Selamoglu, Z. Effects of propolis, caffeic acid phenethyl ester, and pollen on renal injury in hypertensive rat: An experimental and theoretical approach. Cell Biochem. Funct. 2017, 35, 304-314. [CrossRef]

88. Zhou, H.; Wang, H.; Shi, N.; Wu, F. Potential Protective Effects of the Water-Soluble Chinese Propolis on Hypertension Induced by High-Salt Intake. Clin. Transl. Sci. 2020, 13, 907-915. [CrossRef] [PubMed] 
89. Mulyati, A.H.; Sulaeman, A.; Marliyati, S.A.; Rafi, M.; Fikri, A.M. Phytochemical analysis and antioxidant activities of ethanol extract of stingless bee propolis from Indonesia. AIP Conf. Proc. 2020, 2243, 030014. [CrossRef]

90. DeFronzo, R.A.; Ferrannini, E. Insulin resistance: A multifaceted syndrome responsible for NIDDM, obesity, hypertension, dyslipidemia, and atherosclerotic cardiovascular disease. Diabetes Care 1991, 14, 173-194. [CrossRef] [PubMed]

91. Reaven, G.M. Role of Insulin Resistance in Human Disease. In Multiple Risk Factors in Cardiovascular Disease; Springer: Dordrecht, The Netherlands, 1992; pp. 91-97.

92. American Diabetes Association. Diagnosis and classification of diabetes mellitus. Diabetes Care 2009, 32 (Suppl. 1), S62-S67. [CrossRef]

93. Moneta, G.L. Diabetes mellitus, fasting blood glucose concentration, and risk of vascular disease: A collaborative meta-analysis of 102 prospective studies. Yearb. Vasc. Surg. 2011, 2011, 49-51. [CrossRef]

94. Morrison, J.A.; Friedman, L.A.; Wang, P.; Glueck, C.J. Metabolic Syndrome in Childhood Predicts Adult Metabolic Syndrome and Type 2 Diabetes Mellitus 25 to 30 Years Later. J. Pediatr. 2008, 152, 201-206. [CrossRef]

95. Cameron, A.J.; Magliano, D.J.; Zimmet, P.Z.; Welborn, T.A.; Colagiuri, S.; Tonkin, A.M.; Shaw, J.E. The metabolic syndrome as a tool for predicting future diabetes: The AusDiab study. J. Intern. Med. 2008, 264, 177-186. [CrossRef]

96. Shin, J.A.; Lee, J.H.; Lim, S.Y.; Ha, H.S.; Kwon, H.S.; Park, Y.M.; Lee, W.C.; Kang, M.-I.; Yim, H.W.; Yoon, K.H.; et al. Metabolic syndrome as a predictor of type 2 diabetes, and its clinical interpretations and usefulness. J. Diabetes Investig. 2013, 4, 334-343. [CrossRef]

97. Fuliang, H.U.; Hepburn, H.R.; Xuan, H.; Chen, M.; Daya, S.; Radloff, S.E. Effects of propolis on blood glucose, blood lipid and free radicals in rats with diabetes mellitus. Pharmacol. Res. 2005, 51, 147-152. [CrossRef]

98. Li, Y.; Chen, M.; Xuan, H.; Hu, F. Effects of encapsulated propolis on blood glycemic control, lipid metabolism, and insulin resistance in type 2 diabetes mellitus rats. Evid. Based Complement. Altern. Med. 2012, 2012, 981896. [CrossRef] [PubMed]

99. Rivera-Yañez, N.; Rodriguez-Canales, M.; Nieto-Yañez, O.; Jimenez-Estrada, M.; Ibarra-Barajas, M.; Canales-Martinez, M.M.; Rodriguez-Monroy, M.A. Hypoglycaemic and Antioxidant Effects of Propolis of Chihuahua in a Model of Experimental Diabetes. Evid. Based Complement. Altern. Med. 2018, 2018, 4360356. [CrossRef]

100. Matsushige, K.; Basnet, P.; Hase, K.; Kadota, S.; Tanaka, K.; Namba, T. Propolis protects pancreatic $\beta$-cells against the toxicity of streptozotocin (STZ). Phytomedicine 1996, 3, 203-209. [CrossRef]

101. Chen, L.H.; Chien, Y.W.; Chang, M.L.; Hou, C.C.; Chan, C.H.; Tang, H.W.; Huang, H.Y. Taiwanese green propolis ethanol extract delays the progression of type 2 diabetes mellitus in rats treated with streptozotocin/high-fat diet. Nutrients 2018, 10, 503. [CrossRef]

102. Kitamura, H.; Naoe, Y.; Kimura, S.; Miyamoto, T.; Okamoto, S.; Toda, C.; Shimamoto, Y.; Iwanaga, T.; Miyoshi, I. Beneficial effects of Brazilian propolis on type 2 diabetes in ob/ob mice. Adipocyte 2013, 2, 227-236. [CrossRef] [PubMed]

103. Abo-Salem, O.M.; El-Edel, R.H.; Harisa, G.E.I.; El-Halawany, N.; Ghonaim, M.M. Experimental diabetic nephropathy can be prevented by propolis: Effect on metabolic disturbances and renal oxidative parameters. Pak. J. Pharm. Sci. 2009, 22, 205-210. [PubMed]

104. Fukuda, T.; Fukui, M.; Tanaka, M.; Senmaru, T.; Iwase, H.; Yamazaki, M.; Aoi, W.; Inui, T.; Nakamura, N.; Marunaka, Y. Effect of Brazilian green propolis in patients with type 2 diabetes: A double-blind randomized placebo-controlled study. Biomed. Rep. 2015, 3, 355-360. [CrossRef] [PubMed]

105. Zhao, L.; Pu, L.; Wei, J.; Li, J.; Wu, J.; Xin, Z.; Gao, W.; Guo, C. Brazilian green propolis improves antioxidant function in patients with type 2 diabetes mellitus. Int. J. Environ. Res. Public Health 2016, 13, 498. [CrossRef]

106. Gao, W.; Pu, L.; Wei, J.; Yao, Z.; Wang, Y.; Shi, T.; Zhao, L.; Jiao, C.; Guo, C. Serum Antioxidant Parameters are Significantly Increased in Patients with Type 2 Diabetes Mellitus after Consumption of Chinese Propolis: A Randomized Controlled Trial Based on Fasting Serum Glucose Level. Diabetes Ther. 2018, 9, 101-111. [CrossRef]

107. El-Sharkawy, H.M.; Anees, M.M.; Van Dyke, T.E. Propolis Improves Periodontal Status and Glycemic Control in Patients With Type 2 Diabetes Mellitus and Chronic Periodontitis: A Randomized Clinical Trial. J. Periodontol. 2016, 87, 1418-1426. [CrossRef]

108. Chen, J.; Muntner, P.; Hamm, L.L.; Jones, D.W.; Batuman, V.; Fonseca, V.; Whelton, P.K.; He, J. The Metabolic Syndrome and Chronic Kidney Disease in U.S. Adults. Ann. Intern. Med. 2004, 140, 167-174. [CrossRef]

109. Qiu, Y.; Zhao, Q.; Gu, Y.; Wang, N.; Yu, Y.; Wang, R.; Zhang, Y.; Zhu, M.; Liu, X.; Jiang, Y.; et al. Association of Metabolic Syndrome and Its Components with Decreased Estimated Glomerular Filtration Rate in Adults. Ann. Nutr. Metab. 2019, 75, 168-178. [CrossRef]

110. Alizadeh, S.; Esmaeili, H.; Alizadeh, M.; Daneshzad, E.; Sharifi, L.; Radfar, H.; Radaei, M.K. Metabolic phenotypes of obese, overweight, and normal weight individuals and risk of chronic kidney disease: A systematic review and meta-analysis. Arch. Endocrinol. Metab. 2019, 63, 427-437. [CrossRef] [PubMed]

111. Ercan, N.; Erdemir, E.O.; Ozkan, S.Y.; Hendek, M.K. The comparative effect of propolis in two different vehicles; mouthwash and chewing-gum on plaque accumulation and gingival inflammation. Eur. J. Dent. 2015, 9, 272-276. [CrossRef]

112. Eckardt, K.U.; Coresh, J.; Devuyst, O.; Johnson, R.J.; Kottgen, A.; Levey, A.S.; Levin, A. Evolving importance of kidney disease: From subspecialty to global health burden. Lancet 2013, 382, 158-169. [CrossRef]

113. Fu, S.; Yao, Y.; Zhao, Y.; Luan, F. Relationships of hyperhomocysteinemia and hyperuricemia with metabolic syndrome and renal function in Chinese centenarians. Front. Endocrinol. 2018, 9, 502. [CrossRef] [PubMed]

114. Sameni, H.R.; Ramhormozi, P.; Bandegi, A.R.; Taherian, A.A.; Mirmohammadkhani, M.; Safari, M. Effects of ethanol extract of propolis on histopathological changes and anti-oxidant defense of kidney in a rat model for type 1 diabetes mellitus. J. Diabetes Investig. 2016, 7, 506-513. [CrossRef] 
115. Boutabet, K.; Kebsa, W.; Alyane, M.; Lahouel, M. Polyphenolic fraction of Algerian propolis protects rat kidney against acute oxidative stress induced by doxorubicin. Indian J. Nephrol. 2011, 21, 101-106.

116. Bhadauria, M. Propolis Prevents Hepatorenal Injury Induced by Chronic Exposure to Carbon Tetrachloride. Evid. Based Complement. Altern. Med. 2012, 2012, 235358. [CrossRef]

117. Talas, Z.S.; Ozdemir, I.; Ciftci, O.; Cakir, O.; Gulhan, M.F.; Pasaoglu, O.M. Role of propolis on biochemical parameters in kidney and heart tissues against l-NAME induced oxidative injury in rats. Clin. Exp. Hypertens. 2014, 36, 492-496. [CrossRef] [PubMed]

118. Baykara, M.; Silici, S.; Özçelik, M.; Güler, O.; Erdoğan, N.; Bilgen, M. In vivo nephroprotective efficacy of propolis against contrast-induced nephropathy. Diagn. Interv. Radiol. 2015, 21, 317-321. [CrossRef] [PubMed]

119. Izzularab, B.M.; Megeed, M.; Yehia, M. Propolis nanoparticles modulate the inflammatory and apoptotic pathways in carbon tetrachloride-induced liver fibrosis and nephropathy in rats. Environ. Toxicol. 2020. [CrossRef] [PubMed]

120. Ulusoy, H.B.; Ozturk, I.; Sonmez, M.F. Protective effect of propolis on methotrexate-induced kidney injury in the rat. Ren. Fail. 2016, 38, 744-750. [CrossRef]

121. Aldahmash, B.A.; El-Nagar, D.M.; Ibrahim, K.E. Reno-protective effects of propolis on gentamicin-induced acute renal toxicity in swiss albino mice. Nefrologia 2016, 36, 643-652. [CrossRef]

122. Teles, F.; Da Silva, T.M.; Da Cruz, F.P.; Honorato, V.H.; De Oliveira Costa, H.; Barbosa, A.P.F.; De Oliveira, S.G.; Porfírio, Z.; Libório, A.B.; Borges, R.L.; et al. Brazilian red propolis attenuates hypertension and renal damage in $5 / 6$ renal ablation model. PLoS ONE 2015, 10, e0116535. [CrossRef]

123. Da Costa, M.F.B.; Libório, A.B.; Teles, F.; Da Silva Martins, C.; Soares, P.M.G.; Meneses, G.C.; De Paulo Rodrigues, F.A.; Leal, L.K.A.M.; Miron, D.; Silva, A.H.; et al. Red propolis ameliorates ischemic-reperfusion acute kidney injury. Phytomedicine 2015, 22, 787-795. [CrossRef] [PubMed]

124. Chang, J.F.; Hsieh, C.Y.; Lu, K.C.; Chen, Y.W.; Liang, S.S.; Lin, C.C.; Hung, C.F.; Liou, J.C.; Wu, M.S. Therapeutic targeting of aristolochic acid induced uremic toxin retention, SMAD 2/3 and JNK/ERK pathways in tubulointerstitial fibrosis: Nephroprotective role of propolis in chronic kidney disease. Toxins 2020, 12, 364. [CrossRef] [PubMed]

125. Silveira, M.A.D.; Teles, F.; Berretta, A.A.; Sanches, T.R.; Rodrigues, C.E.; Seguro, A.C.; Andrade, L. Effects of Brazilian green propolis on proteinuria and renal function in patients with chronic kidney disease: A randomized, double-blind, placebocontrolled trial. BMC Nephrol. 2019, 20, 140. [CrossRef]

126. Silveira, M.; Teles, F.; Melo, E.; Borges, V.; Miranda, F.; Dutra, F.; Berretta, A.; Cezar, R.; Silva, J.; Santos, H.; et al. P1574Effects of Brazilian Green Propolis Extract (Epp-Af) on Inflammation in Hemodialysis Patients. Nephrol. Dial. Transplant. 2020, 35, gfaa142.P1574. [CrossRef]

127. Younossi, Z.M.; Koenig, A.B.; Abdelatif, D.; Fazel, Y.; Henry, L.; Wymer, M. Global epidemiology of nonalcoholic fatty liver disease-Meta-analytic assessment of prevalence, incidence, and outcomes. Hepatology 2016, 64, 73-84. [CrossRef] [PubMed]

128. Spiritos, Z.; Abdelmalek, M.F. Metabolic syndrome following liver transplantation in nonalcoholic steatohepatitis. Transl. Gastroenterol. Hepatol. 2021, 6, 13. [CrossRef]

129. Muzica, C.M.; Sfarti, C.; Trifan, A.; Zenovia, S.; Cuciureanu, T.; Nastasa, R.; Huiban, L.; Cojocariu, C.; Singeap, A.-M.; Girleanu, I.; et al. Nonalcoholic Fatty Liver Disease and Type 2 Diabetes Mellitus: A Bidirectional Relationship. Can. J. Gastroenterol. Hepatol. 2020, 2020, 6638306. [CrossRef] [PubMed]

130. Chalasani, N.; Younossi, Z.; Lavine, J.E.; Diehl, A.M.; Brunt, E.M.; Cusi, K.; Charlton, M.; Sanyal, A.J. The diagnosis and management of non-alcoholic fatty liver disease: Practice guideline by the American Gastroenterological Association, American Association for the Study of Liver Diseases, and American College of Gastroenterology. Gastroenterology 2012, 142, 1592-1609. [CrossRef]

131. Jin, X.L.; Wang, K.; Li, Q.Q.; Tian, W.L.; Xue, X.F.; Wu, L.M.; Hu, F.L. Antioxidant and anti-inflammatory effects of Chinese propolis during palmitic acid-induced lipotoxicity in cultured hepatocytes. J. Funct. Foods 2017, 34, 216-223. [CrossRef]

132. Ye, M.; Xu, M.; Fan, S.; Zhang, M.; Zhou, B.; Yang, S.; Wei, W.; Ji, C.; Ji, J.; Ji, F. Protective effects of three propolis-abundant flavonoids against ethanol-induced injuries in HepG2 cells involving the inhibition of ERK1/2-AHR-CYP1A1 signaling pathways. J. Funct. Foods 2020, 73, 104166. [CrossRef]

133. Foglia, B.; Cannito, S.; Bocca, C.; Parola, M.; Novo, E. ERK pathway in activated, myofibroblast-like, hepatic stellate cells: A critical signaling crossroad sustaining liver fibrosis. Int. J. Mol. Sci. 2019, 20, 2700. [CrossRef] [PubMed]

134. Oršolić, N.; Sirovina, D.; Končić, M.Z.; Lacković, G.; Gregorović, G. Effect of Croatian propolis on diabetic nephropathy and liver toxicity in mice. BMC Complement. Altern. Med. 2012, 12, 117. [CrossRef] [PubMed]

135. Ibrahim, R.; Amin, A.; Mustafa, I.; Onanuga, I.; Folarin, R.; Balogun, W. Hepatoprotective and Pancreatoprotective Properties of the Ethanolic Extract of Nigerian Propolis. J. Intercult. Ethnopharmacol. 2015, 4, 102. [CrossRef]

136. Nna, V.U.; Bakar, A.B.A.; Mohamed, M. Malaysian propolis, metformin and their combination, exert hepatoprotective effect in streptozotocin-induced diabetic rats. Life Sci. 2018, 211, 40-50. [CrossRef]

137. Ekstedt, M.; Franzén, L.E.; Mathiesen, U.L.; Thorelius, L.; Holmqvist, M.; Bodemar, G.; Kechagias, S. Long-term follow-up of patients with NAFLD and elevated liver enzymes. Hepatology 2006, 44, 865-873. [CrossRef] [PubMed]

138. Kismet, K.; Ozcan, C.; Kuru, S.; Gencay Celemli, O.; Celepli, P.; Senes, M.; Guclu, T.; Sorkun, K.; Hucumenoglu, S.; Besler, T. Does propolis have any effect on non-alcoholic fatty liver disease? Biomed. Pharmacother. 2017, 90, 863-871. [CrossRef]

139. Pai, S.A.; Munshi, R.P.; Panchal, F.H.; Gaur, I.S.; Juvekar, A.R. Chrysin ameliorates nonalcoholic fatty liver disease in rats. Naunyn. Schmiedebergs. Arch. Pharmacol. 2019, 392, 1617-1628. [CrossRef] 
140. Aragno, M.; Tomasinelli, C.E.; Vercellinatto, I.; Catalano, M.G.; Collino, M.; Fantozzi, R.; Danni, O.; Boccuzzi, G. SREBP-1c in nonalcoholic fatty liver disease induced by Western-type high-fat diet plus fructose in rats. Free Radic. Biol. Med. 2009, 47, 1067-1074. [CrossRef]

141. Tailleux, A.; Wouters, K.; Staels, B. Roles of PPARs in NAFLD: Potential therapeutic targets. Biochim. Biophys. Acta Mol. Cell Biol. Lipids 2012, 1821, 809-818. [CrossRef]

142. Samiee-Rad, F.; Bagherkhani, S.; Gheibi, N. Histopathological Examination of the Effects of Oral Consumption of Various Doses of Propolis in Mice Liver. J. Food Nutr. Res. 2019, 7, 785-793. [CrossRef]

143. Soleimani, D.; Rezaie, M.; Rajabzadeh, F.; Gholizadeh Navashenaq, J.; Abbaspour, M.; Miryan, M.; Razmpour, F.; Ranjbar, G.; Rezvani, R.; Jarahi, L.; et al. Protective effects of propolis on hepatic steatosis and fibrosis among patients with nonalcoholic fatty liver disease (NAFLD) evaluated by real-time two-dimensional shear wave elastography: A randomized clinical trial. Phyther. Res. 2020. [CrossRef] [PubMed]

144. Frisardi, V.; Solfrizzi, V.; Seripa, D.; Capurso, C.; Santamato, A.; Sancarlo, D.; Vendemiale, G.; Pilotto, A.; Panza, F. Metaboliccognitive syndrome: A cross-talk between metabolic syndrome and Alzheimer's disease. Ageing Res. Rev. 2010, 9, $399-417$. [CrossRef] [PubMed]

145. Tyagi, A.; Mirita, C.; Taher, N.; Shah, I.; Moeller, E.; Tyagi, A.; Chong, T.; Pugazhenthi, S. Metabolic syndrome exacerbates amyloid pathology in a comorbid Alzheimer's mouse model. Biochim. Biophys. Acta Mol. Basis Dis. 2020, 1866. [CrossRef]

146. Pasinetti, G.M.; Eberstein, J.A. Metabolic syndrome and the role of dietary lifestyles in Alzheimer's disease. J. Neurochem. 2008, 106, 1503-1514. [CrossRef]

147. Raffaitin, C.; Gin, H.; Empana, J.P.; Helmer, C.; Berr, C.; Tzourio, C.; Portet, F.; Dartigues, J.F.; Alpérovitch, A.; BarbergerGateau, P. Metabolic syndrome and risk for incident alzheimer's disease or vascular dementia. Diabetes Care 2009, 32, 169-174. [CrossRef] [PubMed]

148. Isabel Lira-De León, K.; Delia Bertadillo-Jilote, A.; Gustavo García-Gutiérrez, D.; Antonio Meraz-Ríos, M. Alzheimer's Disease and Type 2 Diabetes Mellitus: Molecular Mechanisms and Similarities. In Neurodegenerative Diseases-Molecular Mechanisms and Current Therapeutic Approaches; Working Title; IntechOpen: London, UK, 2020.

149. Luque-Contreras, D.; Carvajal, K.; Toral-Rios, D.; Franco-Bocanegra, D.; Campos-Peña, V. Oxidative stress and metabolic syndrome: Cause or consequence of Alzheimer's disease? Oxid. Med. Cell. Longev. 2014, 2014, 497802. [CrossRef]

150. Wang, X.; Wang, W.; Li, L.; Perry, G.; Lee, H.-G.; Zhu, X. Oxidative stress and mitochondrial dysfunction in Alzheimer's disease. Biochim. Biophys. Acta Mol. Basis Dis. 2014, 1842, 1240-1247. [CrossRef]

151. Spielman, L.J.; Little, J.P.; Klegeris, L. Inflammation and insulin/IGF-1 resistance as the possible link between obesity and neurodegeneration. J. Neuroimmunol. 2014, 273, 8-21. [CrossRef] [PubMed]

152. Minter, M.R.; Taylor, J.M.; Crack, P.J. The contribution of neuroinflammation to amyloid toxicity in Alzheimer's disease. J. Neurochem. 2016, 136, 457-474. [CrossRef]

153. Wu, Z.; Zhu, A.; Takayama, F.; Okada, R.; Liu, Y.; Harada, Y.; Wu, S.; Nakanishi, H. Brazilian green propolis suppresses the hypoxia-induced neuroinflammatory responses by inhibiting NF- B activation in microglia. Oxid. Med. Cell. Longev. 2013. [CrossRef]

154. Li, Z.; Chu, S.; He, W.; Zhang, Z.; Liu, J.; Cui, L.; Yan, X.; Li, D.; Chen, N. A20 as a novel target for the anti-neuroinflammatory effect of chrysin via inhibition of NF-kB signaling pathway. Brain. Behav. Immun. 2019, 79, 228-235. [CrossRef]

155. Tsai, C.F.; Kuo, Y.H.; Yeh, W.L.; Wu, C.Y.J.; Lin, H.Y.; Lai, S.W.; Liu, Y.S.; Wu, L.H.; Lu, J.K.; Lu, D.Y. Regulatory effects of caffeic acid phenethyl ester on neuroinflammation in microglial cells. Int. J. Mol. Sci. 2015, 16, 5572-5589. [CrossRef] [PubMed]

156. Ni, J.; Wu, Z.; Meng, J.; Zhu, A.; Zhong, X.; Wu, S.; Nakanishi, H. The Neuroprotective Effects of Brazilian Green Propolis on Neurodegenerative Damage in Human Neuronal SH-SY5Y Cells. Oxid. Med. Cell. Longev. 2017, 2017, 7984327. [CrossRef]

157. Lu, B.; Nagappan, G.; Lu, Y. BDNF and synaptic plasticity, cognitive function, and dysfunction. Handb. Exp. Pharmacol. 2015, 220, 223-250.

158. Minatohara, K.; Akiyoshi, M.; Okuno, H. Role of immediate-early genes in synaptic plasticity and neuronal ensembles underlying the memory trace. Front. Mol. Neurosci. 2016, 8, 78. [CrossRef]

159. Nanaware, S.; Shelar, M.; Sinnathambi, A.; Mahadik, K.R.; Lohidasan, S. Neuroprotective effect of Indian propolis in $\beta$ amyloid induced memory deficit: Impact on behavioral and biochemical parameters in rats. Biomed. Pharmacother. 2017, 93, 543-553. [CrossRef]

160. Bazmandegan, G.; Boroushaki, M.T.; Shamsizadeh, A.; Ayoobi, F.; Hakimizadeh, E.; Allahtavakoli, M. Brown propolis attenuates cerebral ischemia-induced oxidative damage via affecting antioxidant enzyme system in mice. Biomed. Pharmacother. 2017, 85, 503-510. [CrossRef]

161. Hao, R.; Song, X.; Li, F.; Tan, X.; Sun-Waterhouse, D.; Li, D. Caffeic acid phenethyl ester reversed cadmium-induced cell death in hippocampus and cortex and subsequent cognitive disorders in mice: Involvements of AMPK/SIRT1 pathway and amyloid-tau-neuroinflammation axis. Food Chem. Toxicol. 2020, 144, 111636. [CrossRef] [PubMed]

162. Abbasi, A.; Forsberg, K.; Bischof, F. The role of the ubiquitin-editing enzyme A20 in diseases of the central nervous system and other pathological processes. Front. Mol. Neurosci. 2015, 8, 21. [CrossRef] [PubMed]

163. Zhu, A.; Wu, Z.; Zhong, X.; Ni, J.; Li, Y.; Meng, J.; Du, C.; Zhao, X.; Nakanishi, H.; Wu, S. Brazilian Green Propolis Prevents Cognitive Decline into Mild Cognitive Impairment in Elderly People Living at High Altitude. J. Alzheimer's Dis. 2018, 63, 551-560. [CrossRef] [PubMed] 
164. Czaja, M.J. JNK regulation of hepatic manifestations of the metabolic syndrome. Trends Endocrinol. Metab. 2010, 21, 707-713. [CrossRef]

165. Henao-Mejia, J.; Elinav, E.; Jin, C.; Hao, L.; Mehal, W.Z.; Strowig, T.; Thaiss, C.A.; Kau, A.L.; Eisenbarth, S.C.; Jurczak, M.J.; et al. Inflammasome-mediated dysbiosis regulates progression of NAFLD and obesity. Nature 2012, 482, 179-185. [CrossRef] [PubMed]

166. Esser, N.; Legrand-Poels, S.; Piette, J.; Scheen, A.J.; Paquot, N. Inflammation as a link between obesity, metabolic syndrome and type 2 diabetes. Diabetes Res. Clin. Pract. 2014, 105, 141-150. [CrossRef]

167. Catrysse, L.; van Loo, G. Inflammation and the Metabolic Syndrome: The Tissue-Specific Functions of NF-кB. Trends Cell Biol. 2017, 27, 417-429. [CrossRef]

168. Pahwa, R.; Singh, A.; Adams-Huet, B.; Devaraj, S.; Jialal, I. Increased inflammasome activity in subcutaneous adipose tissue of patients with metabolic syndrome. Diabetes. Metab. Res. Rev. 2020, e3383. [CrossRef] [PubMed]

169. Natarajan, K.; Singh, S.; Burke, T.R.; Grunberger, D.; Aggarwal, B.B. Caffeic acid phenethyl ester is a potent and specific inhibitor of activation of nuclear transcription factor NF-kB. Proc. Natl. Acad. Sci. USA 1996, 93, 9090-9095. [CrossRef]

170. Song, Y.S.; Park, E.H.; Hur, G.M.; Ryu, Y.S.; Lee, Y.S.; Lee, J.Y.; Kim, Y.M.; Jin, C. Caffeic acid phenethyl ester inhibits nitric oxide synthase gene expression and enzyme activity. Cancer Lett. 2002, 175, 53-61. [CrossRef]

171. Márquez, N.; Sancho, R.; Macho, A.; Calzado, M.A.; Fiebich, B.L.; Muñoz, E. Caffeic Acid Phenethyl Ester Inhibits T-Cell Activation by Targeting Both Nuclear Factor of Activated T-Cells and NF-kB Transcription Factors. J. Pharmacol. Exp. Ther. 2004, 308, 993-1001. [CrossRef]

172. Liu, M.; Li, F.; Huang, Y.; Zhou, T.; Chen, S.; Li, G.; Shi, J.; Dong, N.; Xu, K. Caffeic Acid Phenethyl Ester Ameliorates Calcification by Inhibiting Activation of the AKT/NF-kB/NLRP3 Inflammasome Pathway in Human Aortic Valve Interstitial Cells. Front. Pharmacol. 2020, 11, 826. [CrossRef] [PubMed]

173. Bae, Y.; Lee, S.; Kim, S.H. Chrysin suppresses mast cell-mediated allergic inflammation: Involvement of calcium, caspase-1 and nuclear factor-kB. Toxicol. Appl. Pharmacol. 2011, 254, 56-64. [CrossRef] [PubMed]

174. Hori, J.I.; Zamboni, D.S.; Carrão, D.B.; Goldman, G.H.; Berretta, A.A. The inhibition of inflammasome by Brazilian propolis (EPP-AF). Evid. Based Complement. Altern. Med. 2013, 2013, 418508. [CrossRef]

175. Hsieh, C.Y.; Li, L.H.; Rao, Y.K.; Ju, T.C.; Nai, Y.S.; Chen, Y.W.; Hua, K.F. Mechanistic insight into the attenuation of gouty inflammation by Taiwanese green propolis via inhibition of the NLRP3 inflammasome. J. Cell. Physiol. 2019, 234, 4081-4094. [CrossRef]

176. Paulino, N.; Abreu, S.R.L.; Uto, Y.; Koyama, D.; Nagasawa, H.; Hori, H.; Dirsch, V.M.; Vollmar, A.M.; Scremin, A.; Bretz, W.A. Anti-inflammatory effects of a bioavailable compound, Artepillin C, in Brazilian propolis. Eur. J. Pharmacol. 2008, 587, 296301. [CrossRef]

177. Ha, S.K.; Moon, E.; Kim, S.Y. Chrysin suppresses LPS-stimulated proinflammatory responses by blocking NF-kB and JNK activations in microglia cells. Neurosci. Lett. 2010, 485, 143-147. [CrossRef] [PubMed]

178. Funakoshi-Tago, M.; Okamoto, K.; Izumi, R.; Tago, K.; Yanagisawa, K.; Narukawa, Y.; Kiuchi, F.; Kasahara, T.; Tamura, H. Anti-inflammatory activity of flavonoids in Nepalese propolis is attributed to inhibition of the IL-33 signaling pathway. Int. Immunopharmacol. 2015, 25, 189-198. [CrossRef] [PubMed]

179. Ikeda, R.; Yanagisawa, M.; Takahashi, N.; Kawada, T.; Kumazawa, S.; Yamaotsu, N.; Nakagome, I.; Hirono, S.; Tsuda, T. Brazilian propolis-derived components inhibit TNF- $\alpha$-mediated downregulation of adiponectin expression via different mechanisms in 3T3-L1 adipocytes. Biochim. Biophys. Acta Gen. Subj. 2011, 1810, 695-703. [CrossRef] [PubMed]

180. Matsushita, K.; Yatsuya, H.; Tamakoshi, K.; Wada, K.; Otsuka, R.; Takefuji, S.; Sugiura, K.; Kondo, T.; Murohara, T.; Toyoshima, H. Comparison of circulating adiponectin and proinflammatory markers regarding their association with metabolic syndrome in Japanese men. Arterioscler. Thromb. Vasc. Biol. 2006, 26, 871-876. [CrossRef]

181. Shang, H.; Srikanth Bhagavathula, A.; Ali Aldhaleei, W.; Rahmani, J.; Karam, G.; Rinaldi, G.; Clark, C.; Salehisahlabadi, A.; Yuan, Q. Effect of propolis supplementation on C-reactive protein levels and other inflammatory factors: A systematic review and meta-analysis of randomized controlled trials. J. King Saud Univ. Sci. 2020, 32, 1694-1701. [CrossRef]

182. Jalali, M.; Ranjbar, T.; Mosallanezhad, Z.; Mahmoodi, M.; Moosavian, S.P.; Ferns, G.A.; Jalali, R.; Sohrabi, Z. Effect of Propolis Intake on Serum C-Reactive Protein (CRP) and Tumor Necrosis Factor-alpha (TNF- $\alpha$ ) Levels in Adults: A Systematic Review and Meta-Analysis of Clinical Trials. Complement. Ther. Med. 2020, 50, 102380. [CrossRef]

183. Wautier, J.-L.; Guillausseau, P.-J. Diabetes, advanced glycation endproducts and vascular disease. Vasc. Med. 1998, 3, 131-137. [CrossRef]

184. Volpe, C.M.O.; Villar-Delfino, P.H.; Dos Anjos, P.M.F.; Nogueira-Machado, J.A. Cellular death, reactive oxygen species (ROS) and diabetic complications review-Article. Cell Death Dis. 2018, 9, 119. [CrossRef] [PubMed]

185. Wang, X.; Bao, W.; Liu, J.; Ouyang, Y.Y.; Wang, D.; Rong, S.; Xiao, X.; Shan, Z.L.; Zhang, Y.; Yao, P.; et al. Inflammatory markers and risk of type 2 diabetes: A systematic review and meta-analysis. Diabetes Care 2013, 36, 166-175. [CrossRef]

186. Yu, T.; Robotham, J.L.; Yoon, Y. Increased production of reactive oxygen species in hyperglycemic conditions requires dynamic change of mitochondrial morphology. Proc. Natl. Acad. Sci. USA 2006, 103, 2653-2658. [CrossRef] [PubMed]

187. Unoki, H.; Yamagishi, S. Advanced Glycation End Products and Insulin Resistance. Curr. Pharm. Des. 2008, 14, 987-989. [CrossRef]

188. Tahara, N.; Yamagishi, S.I.; Matsui, T.; Takeuchi, M.; Nitta, Y.; Kodama, N.; Mizoguchi, M.; Imaizumi, T. Serum levels of advanced glycation end products (AGEs) are independent correlates of insulin resistance in nondiabetic subjects. Cardiovasc. Ther. 2012, 30, 42-48. [CrossRef] 
189. Coughlan, M.T.; Yap, F.Y.T.; Tong, D.C.K.; Andrikopoulos, S.; Gasser, A.; Thallas-Bonke, V.; Webster, D.E.; Miyazaki, J.I.; Kay, T.W.; Slattery, R.M.; et al. Advanced glycation end products are direct modulators of $\beta$-cell function. Diabetes 2011, 60, $2523-2532$. [CrossRef] [PubMed]

190. Coletta, D.K.; Mandarino, L.J. Mitochondrial dysfunction and insulin resistance from the outside in: Extracellular matrix, the cytoskeleton, and mitochondria. Am. J. Physiol. Endocrinol. Metab. 2011, 301, E749-E755. [CrossRef]

191. Nogueira-Machado, J.A.; Martins Chaves, M. From hyperglycemia to AGE-RAGE interaction on the cell surface: A dangerous metabolic route for diabetic patients. Expert Opin. Ther. Targets 2008, 12, 871-882. [CrossRef] [PubMed]

192. Huttunen, H.J.; Fages, C.; Rauvala, H. Receptor for advanced glycation end products (RAGE)-mediated neurite outgrowth and activation of NF- $\mathrm{KB}$ require the cytoplasmic domain of the receptor but different downstream signaling pathways. J. Biol. Chem. 1999, 274, 19919-19924. [CrossRef] [PubMed]

193. Liu, R.; Wu, C.X.; Zhou, D.; Yang, F.; Tian, S.; Zhang, L.; Zhang, T.T.; Du, G.H. Pinocembrin protects against $\beta$-amyloid-induced toxicity in neurons through inhibiting receptor for advanced glycation end products (RAGE)-independent signaling pathways and regulating mitochondrion-mediated apoptosis. BMC Med. 2012, 10, 105. [CrossRef]

194. Boisard, S.; Le Ray, A.M.; Gatto, J.; Aumond, M.C.; Blanchard, P.; Derbré, S.; Flurin, C.; Richomme, P. Chemical composition, antioxidant and anti-AGEs activities of a French poplar type propolis. J. Agric. Food Chem. 2014, 62, 1344-1351. [CrossRef]

195. Kazemi, F.; Divsalar, A.; Saboury, A.A.; Seyedarabi, A. Propolis nanoparticles prevent structural changes in human hemoglobin during glycation and fructation. Colloids Surf. B Biointerfaces 2019, 177, 188-195. [CrossRef]

196. Boisard, S.; Shahali, Y.; Aumond, M.C.; Derbré, S.; Blanchard, P.; Dadar, M.; Le Ray, A.M.; Richomme, P. Anti-AGE activity of poplar-type propolis: Mechanism of action of main phenolic compounds. Int. J. Food Sci. Technol. 2020, 55, 453-460. [CrossRef]

197. Russo, A.; Longo, R.; Vanella, A. Antioxidant activity of propolis: Role of caffeic acid phenethyl ester and galangin. Fitoterapia 2002, 73, S21-S29. [CrossRef]

198. Kumazawa, S.; Hamasaka, T.; Nakayama, T. Antioxidant activity of propolis of various geographic origins. Food Chem. 2004, 84, 329-339. [CrossRef]

199. Ahn, M.R.; Kumazawa, S.; Usui, Y.; Nakamura, J.; Matsuka, M.; Zhu, F.; Nakayama, T. Antioxidant activity and constituents of propolis collected in various areas of China. Food Chem. 2007, 101, 1383-1392. [CrossRef]

200. Fikri, A.M.; Sulaeman, A.; Marliyati, S.A.; Fahrudin, M. Antioxidant activity and total phenolic content of stingless bee propolis from Indonesia. J. Apic. Sci. 2019, 63, 139-147. [CrossRef]

201. Yuan, W.; Chang, H.; Liu, X.; Wang, S.; Liu, H.; Xuan, H. Brazilian Green Propolis Inhibits Ox-LDL-Stimulated Oxidative Stress in Human Umbilical Vein Endothelial Cells Partly through PI3K/Akt/mTOR-Mediated Nrf2/HO-1 Pathway. Evid. Based Complement. Altern. Med. 2019, 2019, 5789574. [CrossRef]

202. Hotta, S.; Uchiyama, S.; Ichihara, K. Brazilian red propolis extract enhances expression of antioxidant enzyme genes in vitro and in vivo. Biosci. Biotechnol. Biochem. 2020, 84, 1820-1830. [CrossRef]

203. Pazin, W.M.; Mônaco, L. da M.; Egea Soares, A.E.; Miguel, F.G.; Berretta, A.A.; Ito, A.S. Antioxidant activities of three stingless bee propolis and green propolis types. J. Apic. Res. 2017, 56, 40-49. [CrossRef]

204. Pujirahayu, N.; Suzuki, T.; Katayama, T. Cycloartane-type triterpenes and botanical origin of propolis of stingless Indonesian bee tetragonula sapiens. Plants 2019, 8, 57. [CrossRef] [PubMed]

205. Rivera-Yañez, N.; Rivera-Yañez, C.R.; Pozo-Molina, G.; Méndez-Catalá, C.F.; Méndez-Cruz, A.R.; Nieto-Yañez, O. Biomedical properties of propolis on diverse chronic diseases and its potential applications and health benefits. Nutrients 2021, 13, 78 . [CrossRef] [PubMed]

206. Dezmirean, D.S.; Paşca, C.; Moise, A.R.; Bobiş, O. Plant sources responsible for the chemical composition and main bioactive properties of poplar-type propolis. Plants 2021, 10, 22. [CrossRef] [PubMed]

207. Valencia, D.; Alday, E.; Robles-Zepeda, R.; Garibay-Escobar, A.; Galvez-Ruiz, J.C.; Salas-Reyes, M.; Jiménez-Estrada, M.; Velazquez-Contreras, E.; Hernandez, J.; Velazquez, C. Seasonal effect on chemical composition and biological activities of Sonoran propolis. Food Chem. 2012, 131, 645-651. [CrossRef]

208. Regueira, M.S.; Tintino, S.R.; da Silva, A.R.P.; do Socorro Costa, M.; Boligon, A.A.; Matias, E.F.F.; de Queiroz Balbino, V.; Menezes, I.R.A.; Melo Coutinho, H.D. Seasonal variation of Brazilian red propolis: Antibacterial activity, synergistic effect and phytochemical screening. Food Chem. Toxicol. 2017, 107, 572-580. [CrossRef] [PubMed] 